\title{
Effect of Productive Capacities on Economic Resilience in Developing Countries
}

\author{
Author: Sèna Kimm GNANGNON ${ }^{1}$
}

Manuscript date: May 2021

\begin{abstract}
The COVID-19 outbreak and its economic, social and financial fallouts have generated a renewed interest in finding adequate policies and means to strengthen economic resilience to future shocks, particularly in developing countries. The latter are usually disproportionately affected by adverse shocks (compared to developed countries) and lack the adequate resources to weather these shocks. Strengthening economic resilience is now at the heart of the policy discussion both at the national and international levels. The present paper aims to contribute to this debate by investigating the effect of productive capacities on economic resilience in a panel dataset of 118 developing countries over the period 2000-2018. It constructs a regression-based economic resilience indicator, and makes use of the indicator of productive capacities recently developed by the UNCTAD. Results are quite interesting, including from a policy perspective. The development of productive capacities is associated with greater economic resilience. This is particularly the case for countries with greater trade openness, greater capital account openness, and those that promote a stable macroeconomic environment. Interestingly, development aid appears to matter for the effect of productive capacities on economic resilience. On the one hand, the magnitude of the positive economic resilience effect of productive capacities increases as countries receive higher Aid for Trade (AfT) flows. On the other hand, NonAfT flows (i.e., other development aid flows that AfT flows) hinder the possible positive contribution of productive capacities to economic resilience. These findings have important policy implications that are discussed in the paper.
\end{abstract}

Keywords: Productive capacities; Economic resilience; Developing countries.

JEL Classification: D24; F35; O1.

Affiliation: World Trade Organization

Postal Address: Rue de Lausanne 154, CH-1211 Geneva 21, Switzerland.

E-mail: kgnangnon@,yahoo.fr

\section{DISCLAIMER}

This is a working paper, which represents the personal opinions of individual staff members and is not meant to represent the position or opinions of the WTO or its Members, nor the official position of any staff members. Any errors or omissions are the fault of the author. The author declares no competing interests.

\footnotetext{
${ }^{1}$ World Trade Organization (WTO), Geneca, Switzerland. E-mail for correspondence: kgnangnon@ $\varrho_{\text {yahoo.fr }}$
} 


\section{Introduction}

Do productive capacities contribute to fostering economic resilience in developing countries? The present paper aims to address this question, which we believe is timely, as the COVID-19 outbreak has triggered a renewed interest in exploring how countries could recover from the current health shock and its economic and financial fallouts, and prepare for future shocks by strengthening their economic resilience (e.g., OECD, 2020; IMF, 2017, 2021). The focus of the present study on developing countries is simply explained by the fact that while both developed and developing countries are prone to shocks, the frequency of shocks is much higher in developing countries than in developed ones (e.g., Aguiar and Gopinath, 2007; Dabla-Norris and Gündüz, 2014; Guillaumont, 2009). Additionally, these shocks can disproportionately affect developing countries (e.g., Barrot et al. 2018; Harjoto et al., 2020; Keefe, 2021; Lee, 2018; Meierrieks, 2021).

The concept of 'economic resilience' has been used in various fields, such as physical and engineering sciences, ecology, geography, psychology and economics (e.g., Holling (1973; Martin and Sunley 2015). In the field of economics, both Briguglio et al. (2009) and Guillaumont (2009) have, for example, have considered that economic vulnerability and economic resilience are two related concepts. Briguglio et al. (2009) have considered economic vulnerability as inherent permanent (or quasi-permanent) economic features that further expose a country to external shocks, and over which it has almost no control. In contrast, the same authors have defined 'economic resilience' as 'the policy-induced ability of an economy to recover from or adjust to the negative impacts of adverse exogenous shocks and to benefit from positive shocks'. The definitions of economic vulnerability and resilience by Guillaumont (2009) are closed in spirit to those of Briguglio et al. (2009), are similar to those of the United Nations. In fact, Guillaumont (2009) have considered that for a given developing country, the concept of 'economic vulnerability' has two main components, one being structural, and the other being more conjunctural in nature. The structural component is referred to as 'structural economic vulnerability ${ }^{2}$, and reflects the degree of a country's exposure to exogenous shocks, as well as the size and frequency of these shocks. The less structural component is the 'economic resilience', which reflects the country's capacity to react to shocks, such capacity being dependent on recent policy choices that are easily reversible.

The present analysis builds on the definition by Guillaumont (2009) of structural economic vulnerability (originally developed by the United Nations) to compute an indicator of economic resilience, that would be used to examine empirically the effect of productive capacities on economic resilience. Productive capacities ${ }^{3}$ are defined as "the productive resources, entrepreneurial capabilities and production linkages which together determine the capacity of a country to produce goods and services and enable it to grow and develop" (UNCTAD, 2006, p61).

${ }^{2}$ The index of structural economic vulnerability, which has been developed by the United Nations (UN) and calculated on a retrospective basis by the FERDI (see for example, Feindouno and Goujon, 2016), is one of the criteria used by the UN to determine the countries that would be included in the category of least developed countries (LDCs), or the ones that world would graduate from this category. LDCs are defined by the UN as the poorest countries that are concurrently the most vulnerable ones to external and environmental shocks. Further information on the group of LDCs could be found online at: https://www.un.org/ohrlls/content/least-developed-countries

3 The concept of "productive capacities" has also been defined in a different way by other international organizations and bodies, which have focused specifically on some specific aspects of productive capacities, such as the industrial, trade or human capacity facets (UNCTAD, 2006: 62-63). 
The United Nations Conference on Trade and Development (UNCTAD) launched ${ }^{4}$ on 8 February 2021 a comprehensive index of productive capacities (covering the majority of countries in the world and the period 2000-2018). This index would help to assess countries' performance in terms of productive capacities, and allow the research community to undertake analysis and provide guidance on matters related to productive capacities. This index of productive capacities is used to address the issue at the heart of the current analysis.

We are not aware of any previous study that has studied the effect of productive capacities on economic resilience in developing countries. In fact, factors underpinning macro-economic resilience to shocks have been mostly analysed from a regional perspective (e.g., Chacon-Hurtado et al., 2020; Bristow and Healy, 2018; Hundt and Holtermann, 2020; Martin and Sunley 2015; Martini, 2020). Studies at the national level (i.e., country-level) have not really relied on an indicator of economic resilience, but rather assessed countries' economic resilience by comparing their macroeconomic performances before the crises and after the crises (e.g., Alfani et al., 2015; Barthélémy et al., 2020; Furceri and Zdzienicka, 2012; Gupta et al., 2007; Hong and Tornell, 2005; Park and Lee, 2003). The two studies that are closed in spirit to the current analysis are those of Jolles et al. (2018) and Sondermann (2018). Both studies have constructed an indicator of common shocks to countries, which is introduced in an equation where output gap (or GDP growth) depends on a set of countries' structural economic and financial characteristics. The interaction between the shock indicator and variables capturing countries' structural features allow assessing countries' economic resilience. As highlighted above, the present analysis is different from these two studies in two respect. First, it focuses on developing countries whereas Jolles et al. (2018) have used euro area countries, and Sondermann (2018) has relied on country-members of the Organization of Economic Co-operation and Development (OECD). Second, in contrast with both Jolles et al. (2018) and Sondermann (2018), the present analysis develops an indicator of economic resilience, building on the concept of structural economic vulnerability developed by the United Nations.

The empirical analysis utilizes a panel dataset of 118 developing countries over the period 2000-2018, and the two-step system Generalized Methods of Moments (GMM). Findings indicate that greater productive capacities are associated with higher economic resilience. Additionally, the development of productive capacities contributes to strengthening economic resilience in countries that further open-up their economies to international trade and capital flows, as well as those that achieve greater macroeconomic stability (through lower inflation rates). The analysis has also revealed that development aid flows also matter for the effect of productive capacities. Specially, the magnitude of the positive effect of productive capacities on economic resilience consistently increases as countries receive higher amounts of Aid for Trade (AfT) flows. In contrast, productive capacities affect negatively economic resilience as countries receive higher NonAfT flows (i.e., non-trade related development aid).

The rest of the analysis is structured around eight sections. Section 2 discusses how productive capacities could influence economic resilience. Section 3 provides a brief discussion on the definition and assessment of economic resilience in the relevant literature. Section 4 presents the indicator of economic resilience used in the analysis. Section 5 lays out the model specification upon which we rely to conduct the empirical analysis, as well as the econometric approach used to

${ }^{4}$ See information online at: https://unctad.org/fr/node/32056 
perform this analysis. Section 6 presents the estimations' outcomes. Section 7 investigates whether countries' economic and financial features matters for the effect of productive capacities on economic resilience. Section 8 undertakes a further analysis by exploring whether development aid flows that accrue to developing countries matter for the effect of productive capacities on economic resilience. Section 9 concludes.

\section{Theoretical discussion on the effect of productive capacities on economic resilience}

This section discusses theoretically how productive capacities affect economic resilience. According to UNCTAD (2006, p61; 2020), productive capacities are "the productive resources, entrepreneurial capabilities and production linkages which together determine the capacity of a country to produce goods and services and enable it to grow and develop". The UNCTAD has built on this definition of productive capacities to develop an indicator of the overall productive capacities. This indicator covers eight areas, including human capital; physical capital (energy infrastructure; transport infrastructure; information and communication technology, i.e., ICT); private sector; institutions; structural change in production and natural resources (UNCTAD, 2020). This means that improving a country's performance in terms of productive capacities involves acting on these eight areas, including enhancing human capital; developing physical capital (energy infrastructure development; transport infrastructure development; promotion of access to ICT); strengthening the private sector; promoting good institutional and governance quality, enhancing structural change in production and, managing and make effective use of natural resources (UNCTAD, 2020). Therefore, discussing theoretically how the overall productive capacities could influence economic resilience entails discussing how each of these eight components of the overall productive capacities affect economic resilience. In the discussion below, we take up each of these factors, and consider how it could affect economic resilience.

\section{DEffect of human capital on economic resilience}

Building on the conclusion of a recent survey carried out by the World Bank jointly with Georgia government, Fadia $(2021)^{5}$ has pointed out the need for Georgia to increase investments in human capital (complete education and healthcare) so as to build resilience in the face of crises and boosting shared prosperity. This would also prepare the workforce for the highly skilled jobs of the future.

Human capital can affect directly or indirectly economic resilience through various avenues. We highlight some findings that emphasized the critical importance of human capital development in promoting greater resilience.

Briguglio et al. (2009) have argued that human capital development through educational advancement and better health, help to improve a country's ability to withstand external shocks, and improve economic resilience. Mirza et al. (2020) have underlined for Latin American countries, the critical role played by human capital efficiency in financial services like funds management during high turbulence times, such as the COVID-19 pandemic. They have found that equity funds (performance in these funds is driven by investment strategies devised by the portfolio managers)

${ }^{5}$ See the information online at: https:/ /www.worldbank.org/en/news/opinion/2021/01/12/human-capitalinvestments-are-the-key-to-resilient-growth-in-georgia-in-the-era-of-covid-19 
featured by higher human capital efficiency significantly outperformed those with lower levels of human capital efficiency. These findings have not been affected by the escalation of the Covid-19 pandemic, as funds with lower levels of human capital efficiency have continued to experience a degradation of their financial performance compared to those with higher levels of human capital efficiency. The authors have, therefore, concluded that equity funds should enhance their human capital efficiency to endure resilience amid macroeconomic shocks.

Pereira et al. (2020) have looked at the performance of business clusters in pre-recession (2005-2007) and recession (2008-2009) periods, with a view to investigating the relationship between the resilience, human capital of organisations and firm performance. They obtained that human capital plays a leading role in ensuring the success of organizations in business clusters, because organizations with strong human capital exhibited greater resilience during challenging times such as the recent global financial crises.

Cappelli et al. (2021) have explored, for 248 European Union regions, the role played by technological resilience in economic resilience to the 2008 financial crisis. Technological resilience reflects the technological resistance, i.e, the historical ability of a region to maintain its level of knowledge creation in the face of adverse shocks. Economic resilience is measured by the difference between the level of unemployment rate before the 2008 crisis and the level of unemployment rate at its peak after the crisis. Their findings are quite interesting and suggest a strong positive effect of technological resistance (that is, past ability of regions to sustain the production of knowledge) on the capacity of regional economic system (in term of unemployment rates) to resist to the 2008 crisis. Furthermore, and interestingly, human capital is critical in this relationship. While after the crisis, human capital alone was not able to support the resilience of the regional system, its interaction with technological resilience does so. Specifically, human capital combined with a general ability of the region to re-orient innovative resources and technologies were able to shape a new growth path.

According to Bowen et al. (2012), investment in skills and access to finance reduce vulnerability to climate change. Mayunga (2007) has stressed that human capital (i.e., education, health, skills, knowledge and information) can enhance a country's capacity to develop and implement an effective risk reduction strategy, and thereby act as an important contributing factor to resilience to climate change.

Other recent studies have also demonstrated empirically that human capital development is essential for ensuring greater economic resilience (e.g., Lagravinese, 2015; Martini, 2020).

\section{Effect of Physical infrastructure on economic resilience}

The literature has emphasized the criticality of hard infrastructures (energy, including electricity, transport), notably its structure and quality for the build-up and strengthening of resilience to economic and financial shocks as well as natural disasters (e.g., Bristow and Healy, 2020; Chiu et al., 2020; Di Caro and Fratesi, 2018; Hallegatte, 2014; Lagravinese, 2015; United Nations, 2016). For example, natural disasters cause disruption in the afore-mentioned infrastructures - in particular if they are of complex nature, and highly interconnected ${ }^{6}$ - and induce major adverse effects on the economy and functioning of society (e.g., Berche et al., 2009; United Nations, 2016). Fried and Lagakos (2021) have found that rural electrification helped facilitate

\footnotetext{
${ }^{6}$ In this case, infrastructures are vulnerable to chain reaction effects during crisis (e.g., Van Eeten, 2011).
} 
structural transformation of villages economies in Ethiopia. Chacon-Hurtado et al. (2020) have considered whether transportation infrastructure contributes to the build-up of robust regional economies, using data on six states of the Unites States of America during the last recession (20082009) and post-recession (2010-2014). They have found that rail density, access to intermodal services, and access to local and regional markets have exerted a positive effect on regional performance (measured as competitive effect) during the recession. The authors have then concluded that the transportation infrastructure was critical in determining the regions' ability to strengthen their resilient to economic shocks.

By promoting economic transformation, infrastructure development can help dampen output volatility (e.g. Moro, 2012; 2015), and hence be associated with greater economic resilience. In addition, economic transformation create job opportunities and decent jobs, as well as high productivity gains, notably in poor countries (e.g., Diao et al., 2018; McMillan et al., 2014) that could help recovering easily after negative shocks. Jiya et al. (2020) have demonstrated that energy infrastructure (electricity, and telecommunication related infrastructure) is critical to achieve economic transformation.

The effect of the development of ICT on economic resilience can take place through the innovation channel. On the one hand, countries that have endeavoured to develop ICT have enjoyed a higher innovation performance than countries with lower levels of ICTs. For example, Higón (2012) has used data on small and medium-sized enterprises (SMEs) of the United Kingdom to examine the effect of ICT on the innovation performance. The author has found that ICT improves firms' innovation performance by primarily enhancing the efficiency of technologies, although specific market-oriented applications (that is, website development) have appeared to show the potential to create competitive advantage through product innovation. Paunov and Rollo (2016) have obtained that industries' use of the Internet has positively affected investment in equipment by firms with adequate absorptive capabilities, and resulted in strong innovation performance. Bas (2020) has demonstrated that communication and energy-services liberalization enhance investment in Research and Development (R\&D) and exert a strong positive effect on innovation, including manufacturing firms' innovation.

On the other hand, innovation has been instrumental in promoting resilience, including economic resilience ${ }^{7}$. For example, Tambo and Wünscher (2017) have found that innovations have contributed significantly to enhancing the resilience to climate shocks of northern Ghana's rural farm households that adopted externally driven technologies to develop their very own innovations. Bristow and Healy (2018) have considered the relationship between innovation and economic resilience at the regional level, and examined empirically for the European Union (as a region) how innovation capacity influences resilience of European regions to the crisis. They have obtained that regions that were leaders in innovation at the time of the 2007 to 2008 economic crisis were significantly more likely to have either resisted the crisis or recovered quickly from it (that is, within 3 years). As noted above, Cappelli et al. (2021) have also found for European Union regions that technological resilience is key for economic resilience in countries with strong human capital. The current COVID-19 pandemic has demonstrated how the technology-driven innovation can contribute to the discovery and production of vaccines, which would help enhance

7 Bahadur and Doczi (2016) have provided an extensive discussion on how innovation and autonomous innovation can help communities reduce risk and enhance resilience to shocks. 
the resilience of countries to health shocks, and the associated adverse economic and social consequences of these shocks (e.g., Farrugia and Plutowski, 2021; Paunov and Planes-Satorra, 2021; Ramalingam and Prabhu, 2020; Woolliscroft, 2020).

Overall, we expect that the development of ICT would contribute to enhancing economic resilience through greater innovation performance.

\section{Effect of the private sector development on economic resilience}

A strong private sector reflects competitive and well-functioning product markets. Factors that can affect the degree of competition in product markets include barriers to entrepreneurship (for example, licenses and permit systems and administrative burdens), and barriers to trade and investment (such as differential treatment of foreign suppliers and barriers to FDI) as well as state control such as price controls and government involvement in network industries (e.g., Jolles et al., 2018; Seidu and Maciej, 2020). A well-developed private sector, exemplified for example by a strong development of entrepreneurial activities, may signal market efficiency at the microeconomic level. In this case, the private sector would be able to easily withstand shocks through a better allocation of resources in the economy, and allow for the markets to adjust to shocks (e.g., Briguglio et al. 2009). Sánchez et al. (2016) have highlighted some possible channels through which pro-competitive product market regulations can enhance resilience. These include price and wage flexibility, including by limiting the oligopolistic behaviour of firms and disciplining mark-ups (Canova et al., 2012), resources reallocation, and innovation. For example, Geroski (1992) has shown that enhancing competition among industries allows for a fast response of prices to both supply and demand shocks. According to Álvarez and Hernando (2007), product market regulations that encourage competition, make prices more flexible, and allow firms in more competitive markets to adjust quickly prices in response to demand and supply shocks.

As also emphasized by Sánchez et al. (2016), flexible product markets contribute to a better improvement of the labour market functioning by speeding the pace of adjustment (e.g., Bassanini and Duval, 2006). Andrews and Saia (2017) have shown that the conditions associated with entrepreneurship framework influence directly the entry and exit of firms, and therefore affect the reallocation of resources during recovery after negative shocks. According to Anderton et al. (2020), policies that enhance competition in product markets facilitate business churning. As for the resources reallocation avenue, pro-competitive product market regulations allow for easier entry and exit from the market. In turn, this could help dampen the impact and speed up the recovery from shocks by enabling a quicker and more efficient reallocation of resources within and across sectors and firms (e.g., Sánchez et al. 2016). Lastly, pro-competitive product market regulations can provide strong incentives to firms to innovate when faced by an adverse shock, and therefore facilitate the speed up and recovery from the shock. It is worth noting that the relationship between competition and innovation performance takes a curvilinear form, i.e., the form $^{8}$ of an inverted-U. Sondermann (2018) has found, inter alia, that sound labour and product markets, and conditions for doing business improve the resilience of the euro area towards adverse shocks. The author has also uncovered that in the presence of a common shock to the euro area, a country with weak labour and product markets, and unfavourable business environment can, on

${ }^{8}$ See for example, Aghion et al. (2005) and Aghion et al. (2015) who have built upon the seminal wo rks of Arrow (1962) and (Schumpeter, 1994[1942]). 
average, suffer up to twice the output loss in a given year compared to a more adaptable economy. Aarstad and Kvitastein (2020) have looked at the effect of an unexpected external economic shock (which decreases demand and increases competition) on innovation performance. Using data on Norwegian enterprises before and after the sudden and unexpected price decline of crude oil by the midyear of 2014, the authors have found that better access to resources released in affected regions (associated with increased competition) allows enterprises that were not innovative before the shock to exhibit a strong innovation performance after shock. Finally, a high degree of product market competition can help to increase resilience by facilitating the transmission of monetary and fiscal impulses, including after adverse shocks (e.g., Aghion et al., 2019; Duval and Furceri, 2018).

Against this background, we can expect that the development of the private sector would be associated with greater economic resilience.

\section{$>$ Effect of institutional and governance quality on economic resilience}

According to Acemoglu et al. (2003), a weak institutional quality exposes a country to higher levels of social unrest, disrupting growth, and hence limits significantly its ability to cope in an appropriate manner external economic shocks (see also Caldera Sánchez and Röhn, 2016, Loayza et al., 2007; Rodrik, 1999). Acemoglu et al. (2020) have argued that in contrast with the general belief of institutional stasis, institutions are rather in a constant state of flux, even though past institutional choices may affect their trajectory. They have then discussed how institutions can be designed to bolster economic stability.

Farrugia (2007) have argued that in light of their high exposure to external shocks, small island states should set-up institutions that promote economic resilience. The role of these institutions include for example ensuring the enforcement of rules and laws (e.g., securing property rights), enhancing governance, and improving public administrative and regulatory systems. In addition, sound institutions are needed to promote macroeconomic stability (e.g., Thorbecke and Pangestu, 1998), financial stability (e.g., Bermpei et al., 2018; Boulanouar et al., 2021; Owoundi et al., 2021). In addition, by allowing wages adjustment (including through wage coordination) to changes in macroeconomic conditions, coordinated collective-bargaining institutions would exert a positive effect on economic resilience (e.g., OECD, 2012). In the same vein, Zeev and Ifergane (2021) have examined the role of firing restrictions (set up by labour market institutions through employment protection legislation) in the transmission of macroeconomic shocks to the real economy. Their theoretical model has postulated that further to an adverse shock, firing restrictions amplify macroeconomic shocks through misallocation of labour resources, and result in output losses. They have uncovered empirically that firing restrictions reduce economic resilience in OECD countries. This is due to the fact that immediately after an adverse shock, strict firing restrictions legislations are associated with a weak response of the labour market. This initial response of the labour market is then followed by a stronger and more persistent fall in real output, and a slower return of real activity to pre-shock levels. In other words, labour market institutions that promote employment legislation in favour of strict firing restrictions are not conducive to a strong economic resilience. According to OECD (2017), enhancing economic resilience in the long term requires the strengthening of pension and health systems so as to allow countries to be in a better capacity to deal with population aging and mitigating pressures on public finances. More generally, countries should reform social institutions by developing automatic adjustment mechanisms that would permit them to adjust gradually to secular changes, and ensure a higher degree of 
intergenerational fairness (Fall et al, 2014). Stronger public administrations improve countries' ability to implement good quality policies, and solve coordination failures across different parts of the administration (e.g., OECD, 2017). The institutional quality can also influence the level of economic resilience via its effects on economic diversification. Olander (2019) has provided empirical support to their argument that a greater economic diversification reduces collusion among elites, and forces them to settle more impartial institutions. As a result, economic resilience is likely to be weaker in countries that specialize in less sophisticated goods (as in such countries, institutions would be weak) than in countries that produce sophisticated goods and services. Finally, by helping to mitigate the volatility of output (e.g., Balavac and Pugh, 2016; Ghosh, 2013), improved institutional quality can contribute to building greater economic resilience. Jolles et al. (2019) have found empirically that good governance exerts a positive effect on the economy's recovery capacity, but weakens the economy's absorption capacity. The authors concluded that the latter's finding (i.e., the one concerning the absorption capacity) may reflect the existence of an ineffective administration that has contributed to the slowdown of the recovery by maintaining zombie firms longer in business.

\section{$>$ Effect of structural change in production on economic resilience}

According to Herrendorf et al. (2014, p. 857), structural change ${ }^{9}$ in the production of an economy (also termed 'structural change in production' or 'structural transformation') is defined in a narrow sense as a reallocation of economic activity across three broad sectors (agriculture, manufacturing, and services) that accompanies the process of modern economic growth.

While as mentioned above, some studies have examined the effect of structural change on output volatility, and therefore allow to infer on how structural change can affect economic resilience, the relationship between structural change and economic resilience has mainly been considered from a regional perspective. Davies and Tonts (2010) have argued that the greater the diversity of a region's economy (i.e., the larger its economic base), the more resilient to shocks the region is. Along the same lines, Martin and Sunley (2015: p26-27) have postulated that a diverse economic structure should not only reduce the vulnerability of a region to shocks (a portfolio effect), but also allow it to recover more rapidly further to a shock (an innovation and market opportunity effect). It, therefore, follows that a region specialized in a narrow range of activities will be both exposed to idiosyncratic sector-specific shocks, and have fewer opportunities to reorientate its economy. As a result, such a region would have lesser alternative ways to recover from an adverse shock. Additionally, in the event the region would specialize, the type of specialization matters. A specialization in a sector (e.g., computer software or biotechnology) that has many implications for the region's economic resilience would be more beneficial to the region than a specialization in a sector whose spillovers for the region are fewer (e.g., steel production or heavy engineering). Briguglio et al. (2009) have argued that the ability of an economy to recover from adverse shocks depends on its flexibility, which would enable it to bounce back after being hit by an adverse shock. Jolles et al. (2019) have postulated that the diversification of economic activity increase countries' level of flexibility in being capable of adapting to changing economic conditions, and hence in enhancing their capacity to absorb and recover from shocks. However,

9 See Atolia et al. (2020) for a discussion on the potential benefits of structural transformation and the prospective future paths for structural transformation and development policies. 
the authors obtained empirically that sectoral diversity in domestic production had exerted a small impact on economic resilience in the euro area countries, although stronger export product specialization has strengthened the capacity to absorb a common shock, but weakened the capacity to recover.

This argument developed by Martin and Sunley (2015: p26-27) applies at the national (i.e., country) level. We postulate that a country with a narrow economic base (i.e., a less diversified economic structure, particular relying on low value-added products or services items) are likely to be more vulnerable to shocks, and to experience a weaker ability to recover after an adverse shock. This signifies that poor countries that have an undiversified economy (or a very low degree of diversification of economic structure) would experience a lower degree of economic resilience than other countries whose economic base is larger. At the same time, a country that produces very few but highly sophisticated goods and services may also experience a low degree of economic resilience, even though such a country might be more resilient to adverse shocks than a country that relies essentially on the production of primary commodities (whose prices are highly volatile and that has limited economic spillovers in the country). From an empirical perspective, some studies carried out at the country level have shown that structural change is associated with lower output volatility (e.g., Moro, 2012; 2015; Ngouana, 2013). This, therefore, suggests that structural change can be associated with greater economic resilience. In fact, Moro (2012) has reported a negative effect of structural change on the volatility of GDP as well as the volatility of each broad component of GDP (manufacturing consumption, services consumption and investment). Furthermore, Moro (2015) has shown for example that an increase in the share of services in GDP dampens economic growth volatility. A similar finding has been reported by Ngouana (2013), that is, the secular shift of labor towards the service sector has reduced economic volatility in OECD countries during the period 1970-2006. Xiaohui et al (2020) have investigated how industrial structure affects regional economic resilience at different stages, using data on resource-based cities in China. They have observed that industrial diversification had positively influenced economic resilience, whereas industrial specialization had weakened it, notably in mining cities.

Overall, we expect that a greater extent of structural change, including across many sectors of the economy, would lead to a stronger economic resilience.

\section{$>$ Effect of natural resources on economic resilience}

There is a voluminous literature on whether abundance of or dependence on natural resources is associated with resource curse or inversely with a resource blessing (e.g., Kolstad, 2008; Morrison, 2012; Robinson et al., 2014; Sachs and Warner, 2001; Smith, 2015; van der Ploeg, 2011). Natural resources dependence or abundance can help build economic resilience if countries utilize effectively and efficiently resource revenue to create opportunities and employment, develop the private sector, and transform the structure of the economy away from natural resource production towards high value-added products (e.g., OECD et al., 2013; Muhamad et al., 2021). In contrast, a high endowment in natural resources can hinder the development process by lowering levels of physical and human capital accumulated, lead to high corruption, bad institutional and governance quality. It can also be associated with the absence of policies and regulations to promote the development of the private sector, the lack of structural transformation, the absence of democracy, and greater political instability (e.g., Henri, 2019). In this scenario, it would be associated with lower economic resilience. For example, Agüero et al. (2021) have 
explored how natural resources affect human capital formation in a country with low quality of governance (i.e., Peru). They have obtained that redistribution of mining taxes to local governments increase substantially students learning. This is because these transfers have helped to increase school expenditure and infrastructure, and to improve health outcomes of adults and children. However, the effect becomes negative for very large transfers. As a result, the redistribution of resource rents can help to build-up economic resilience through its effect on human capital.

Faha (2021) has found that the effect of natural resources on internal conflicts depends on the type of natural resources, and might increase internal conflicts as the volume of natural resources increases. This signifies that if natural resources resulted in internal conflicts, it would erode economic resilience. Chenaf-Nicet (2020) has obtained empirical findings that the specialization on natural resource production by Sub-Saharan African (SSA) countries exerts a detrimental effect on structural change. It follows that a high dependence on natural resources can lead to a greater natural resource-based specialization in a country will inhibit the process of structural change, including toward higher value-added production (see also Oyinlola et al., 2020). Overall, unless wisely utilized, natural resources could deter structural change and reduce the capacity of the country to build-up strong economic resilience. Morck and Nakamura (2018) illustrated for the case of Japan that the government's attempt of initial industrialization (1880s1930s) relied on natural resources, but failed because the state used mines resources to subsidize state-owned industrial firms. However, the post-World War II reconstruction was successful in exorcised a natural resources curse, and promoting industrialization. The post-World War II industrialization strategy relied little on natural resources and more on bank financing, as well as on free markets, openness and limited government.

\section{Brief literature review on the definition and measurement of economic resilience}

The concept of 'resilience' has been used in various areas, in particular since the seminal work by Holling (1973). 'Resilience' has been considered not only in the physical and engineering science, but also in the ecology field, including in relation to natural hazards, in psychology, geography, economics, and in relation to sustainable development matters (that encompass environmental, social and economic matters). According to Holling (1973), resilience, also termed 'engineering resilience' (in reference to its interpretation in many physical and engineering sciences) can be defined as how fast a system that has been displaced from equilibrium by a disturbance or shock returns to that equilibrium. Thus, for Holling (1973), the idea of 'bounce back' is at the heart of the concept of 'resilience'. In this regard, Holling (1973) has defined the notion 'ecological resilience' as the ability of a system to absorb a shock without changing its structure, identity, and function. In the mainstream economics, he has related 'resilience' to the idea of 'self-restoring equilibrium dynamics', whereby when an economy is pushed away by a shock from its normal condition (e.g., a steady state), self-correcting market mechanisms (through free operation of market forces) are automatically activated to bring back the economy to its ex-ante equilibrium.

In economics, the concept of 'economic resilience' has usually been associated with that of economic vulnerability, and considered in the macroeconomic sense, from both a national and regional perspectives (including in the economic geography field for the regional perspective). 
Building on earlier studies ${ }^{10}$, many other studies ${ }^{11}$ have been conducted on the matters of economic vulnerability and resilience. According to this literature, both economic vulnerability and resilience determine jointly determine the risk that a country would be affected by external and environmental shocks. Briguglio et al. (2009) have considered economic vulnerability as inherent permanent (or quasi-permanent) economic characteristics that increase a country's exposure to external shocks, and over which it has almost no control, at least in the short run. These features (economic openness, export concentration, and dependence on strategic imports of the country in question) represent a disadvantage to the country's economic development, as they magnify the element of risk in the growth process, without necessarily compromising the overall viability. 'Economic Resilience' has been defined by Briguglio et al. (2009) as the policy-induced ability of an economy to recover from or adjust to the negative impacts of adverse exogenous shocks, and to benefit from positive shocks. Such policies involve enhancing macroeconomic stability, increasing market efficiency, improving governance and expanding social development. Put it differently, economic resilience encompasses both the ability to recover quickly from a shock, and to withstand the effect of a shock.

For Guillaumont (2010), a country's economic vulnerability can be defined as the risk of a (poor) country seeing its development hampered by the environmental or natural shocks as well as external shocks. Natural shocks are for example earthquakes, volcanic eruptions and climatic shocks, while external shocks can include trade shocks, exchange rate shocks, fluctuations in foreign demand, commodity prices fluctuations, volatility of interest rate in the international financial market, and volatility of capital flows. Hence, according to (Guillaumont, 2010: p830), economic vulnerability arises from three main elements: the size and frequency of exogenous shocks, either observed (ex-post vulnerability) or anticipated (ex-ante vulnerability); exposure to shocks; and resilience (i.e., the capacity to react to shocks). In other words, economic vulnerability has a structural component, termed 'structural economic vulnerability' and a less structural including more conjunctural - (i.e., policy-related) component, termed 'economic resilience'. Structural economic vulnerability results from factors over which a country has little control, at least in short term, while 'economic resilience' depends on recent policy choices, and is less structural and easily reversible. The concept of 'structural economic vulnerability' is at the heart of the international economic policy agenda of the United Nations (UN), as the latter uses the index of structural economic vulnerability (computed based on the concept of 'structural economic vulnerability') as one of the criteria to include or graduate countries in the world from the group of Least developed countries ${ }^{12}$ (LDCs).

Besides the relatively limited literature on economic vulnerability and resilience at the national (country) level, a voluminous empirical literature has considered economic resilience from a regional perspective. Regional economic resilience ${ }^{13}$ has been defined, for example, as "the capacity

${ }^{10}$ See for example, Atkins et al. (2000), Briguglio (1995, 2004), Briguglio and Galea (2003), Cordina (2004a, 2004b), Encontre (1999), and Guillaumont (2004).

11 These studies include for example Briguglio et al. (2009), Briguglio (2016), Gnangnon (2013, 2014, 2016, 2017, 2019a,b), Gnangnon and Iyer (2017), Guillaumont (2009, 2010, 2015, 2017), Guillaumont and Wagner (2012), Wagner (2014) and Yohou and Goujon (2017).

12 The category of LDCs was first established by the United Nations at its General Assembly in 1971. Information on the set of criteria used to designate a country as an LDC or to graduate it from the LDC category is provided by the United Nations online at: https://www.un.org/ohrlls/content/least-developed-countries

${ }^{13}$ Martin and Sunley (2015) provided a literature review on definitions and applications of the concept of 'resilience'. 
of a regional or local economy to withstand, recover from and reorganize in the face of market, competitive and environmental shocks to its developmental growth path" (Bristow and Healy, 2018: p.268) (see also Brada et al., 2021; Bristow and Healy, 2014, 2015; Boschma 2015; Hundt and Holtermann, 2020; Martin and Sunley 2015).

The empirical part (if any at all) of the above-cited studies on economic vulnerability and resilience conducted at the country level, has paid little attention to the economic resilience aspect of country's macroeconomic vulnerability: focus has mainly been on the 'structural economic vulnerability' aspect of macroeconomic vulnerability, and empirical studies on economic resilience are scarce. For example, Briguglio et al. (2009) were among the rare studies that relied on a genuine indicator of economic resilience (in the sense of a macroeconomic resilience of a country) to provide a raw estimation of the effect of economic vulnerability and resilience on the Gross Domestic Product (GDP) per capita over a set of 86 countries. Their estimation by the ordinary least squares (OLS) estimator by a simple regression of economic vulnerability and economic resilience on the per capita GDP revealed a positive and statistically significant effect of economic resilience on GDP per capita, but a negative and significant effect of economic vulnerability on GDP per capita. The coefficient associated with the index of economic resilience (0.95) is far higher than that of the index of economic vulnerability (which is -0.14) in explaining real GDP per capita.

Guillaumont (2017) had not provided an evidence-based analysis on the effects or determinants of economic resilience. Rather, he discussed the possible measurements of economic resilience (Guillaumont (2017, page 12). For example, he argued that the multiplicity of factors that can influence economic resilience makes it difficult to measure the extent of economic resilience. One proposed way to measure this concept has been suggested by Guillaumont (2017) and entails regressing economic growth volatility on the indicator of structural economic vulnerability (as defined by Guillaumont, 2009 and the United Nations) over a large sample of countries, and extracting the residual of this regression as a proxy for economic resilience. In such a case, the computed indicator of economic resilience would reflect the part of economic growth volatility not explained by structural economic vulnerability. It can, therefore, incorporate structural factors of economic resilience, such as the level of human capital and income per capita. However, if these two latter factors were included in the regression, then the computed indicator of resilience might be capturing non-structural elements of resilience. Notwithstanding this, Guillaumont (2017) has underlined some limitations of this proposed measure of economic resilience. These included the method used to estimate economic growth volatility, and the possible omission of structural factors of volatility in the regression. Another measure of economic resilience has also been proposed by Guillaumont (2017), and consists of taking into account the fact that resilience may also operate through a weak transmission of growth volatility to the average growth rate. This involves measuring economic resilience by the residual of the regression of the average growth rate over the growth volatility, along with other structural factors. A proxy for total resilience in terms of economic growth can also be computed by the residual extracted from the regression of the average growth rate on the indicator of structural economic vulnerability. Finally, an indicator of economic resilience may be envisaged as a weak reaction of social variables (e.g., poverty, crime, corruption) to exogenous shocks and income volatility, in a cross-country regression, or as a weak reaction of gross national happiness to exogenous shocks. 
Two important studies (among the rare ones) on the macroeconomic resilience (at the country level) are worth highlighting here. These included the works respectively by Jolles et al. (2018) and Sondermann (2018). Jolles et al. (2018) have examined the structural macroeconomic features that matter the most for a country's economic resilience in the euro area. Enhancing economic resilience involves not only reducing the countries' vulnerability to shocks, but also increasing both their shock-absorption capacity, and their ability to reallocate resources and recover from the shocks (Jolles et al. 2018: p 27). The study has used the common shocks that affected countries in the euro area to address the question at hand. The reliance on the common shocks (i.e., the size of shocks, regardless of their nature) is attributed to the fact that the main objective of the study is to examine the structural characteristics that allow countries to better cope with adverse shocks. It is, therefore, assumed that the outcomes arising from their analysis would hold for idiosyncratic shocks. The common shock indicator for the 17 countries considered in the analysis was estimated in a panel setting as a deviation of GDP from its trend. The authors have then moved on to estimating an output gap autoregressive econometric equation in a panel setting of 17 countries in the euro area over the period 1998-2015, to derive each country's absorption capacity and the speed of recovery. The absorption capacity of each country is defined as the response coefficient to the common shocks indicator in the equation, while the speed of recovery is obtained as the response coefficient of the lagged output gap, and depends on country specific structural characteristics. In this analytical framework, an economy is qualified as being more resilient than another after a common shock if it performs better than it after the shock. The empirical exercise suggested that the well-functioning of markets (i.e., product markets, labour markets and financial markets) are the most important drivers of economic resilience in the euro area. Structural factors such as trade openness and export product diversification also influence positively economic resilience.

Sondermann (2018) has also used an approach similar to that of Jolles (2018) to investigate the effect of economic structures on economic resilience in OECD countries, over the period 1986-2014. Economic structures encapsulate the efficiency of labour and product market policies, the framework conditions of doing business, and the interaction between the government and the economy. Their results suggest that sound labour and product markets, framework conditions and political institutions foster countries' resilience to adverse shocks and more generally, reduce the incidence of crises.

Other related macroeconomic studies at the country-level (and not regional level) considered economic resilience from a slightly different perspective, i.e, essentially in the sense of 'economic recovery'. For example, some studies have explored the delay and the strength with which the economy rebounds followed the recession trough in developing countries, using static comparisons of countries' macroeconomic performances before the crises and after the crises in the short run (e.g., Alfani et al., 2015; Dao, 2017; Gupta et al., 2007; Hong and Tornell, 2005; Park and Lee, 2003; Wise et al., 2015). Other works have taken account of the post-crisis dynamics of countries' economic recovery (i.e., the dynamics of output in the medium term) when comparing countries' pre-crisis and post-crisis macroeconomic performances (e.g., Barthélémy et al., 2020; Furceri and Zdzienicka, 2012; IMF, 2017, 2018; 2021; Kannan, 2012). 


\section{Our measurement of economic resilience}

As underlined above, to assess countries' level of economic resilience, many studies at the country-level were conducted on the determinants of countries' economic recovery. To the best of our knowledge, there is no deep study carried out on the macroeconomic determinants of the level of overall economic resilience in a country. Even the recent work by Jolles et al. (2018) and Sondermann (2018) that have explored the macroeconomic determinants of economic resilience have not used an indicator of economic resilience as a dependent variable. Rather, the authors constructed an index of 'common' shocks that affected all countries together in the euro area and then estimated an equation to assess the level of economic resilience.

The present study investigates the effect of productive capacities on economic resilience by developing an indicator of economic resilience. Inspired by Guillaumont (2017), we construct an indicator of macroeconomic resilience at the country level by regressing a measure of economic growth volatility on the index of structural economic vulnerability (EVI) (see Appendix 1 for details concerning the computation of this index). The residual of this regression is considered as the indicator of economic resilience. The economic growth volatility indicator has been computed as the rolling window standard deviation of the economic growth rate over a three-year-window (see also Bekaert et al. 2006; Ebeke and Ehrhart, 2012; Museru et al., 2014). The real GDP growth (constant 2010 US\$) variable is collected from the World Bank Development Indicators (WDI). The estimation is performed using a panel dataset of 118 developing countries over the period 2000-2018, based on available data.

It is important to note that the regression of the volatility of the real GDP growth on EVI did not contain time dummies, as the latter were included in the model that helped to investigate the effect of productive capacities on economic resilience. This equation is primarily estimated by the two-step system Generalized Methods of Moments (GMM) estimator of Blundell and Bond (1998). Utilizing this estimator involves estimating a system of equations, that is, an equation in first-differences and equation in the levels, where lagged first differences are used as instruments for the level equation, and lagged levels are used as instruments for the first-difference equation. There are three conditions for the validity of the two-step system GMM approach - that is, we should not reject the null hypothesis of each of the following three tests: the Arellano-Bond test of the presence of first-order serial correlation in the residuals of the equations in level (denoted $\mathrm{AR}(1)$ ), the Arellano-Bond test of no second-order autocorrelation in the residual in the differenced equation (denoted AR(2)); and the Sargan/Hansen test of over-identifying restrictions (OID), the null hypothesis being here that the instruments used in the regression are jointly valid. To meet these requirements when regressing the economic growth volatility indicator on the EVI indicator, we used two lags of the dependent variable, as using only one lag of economic growth volatility indicator did not help meet these conditions associated with the consistency of the twostep system GMM estimator. We also made sure that there is no over-instrumentation, that is, the number of instruments is lower than the number of countries in the sample.

The usefulness of this estimator resides in its ability to help handle the possible endogeneity of the "EVI" indicator in the regression of economic growth volatility on EVI. In fact, a rise in a country's level of EVI means that this country faces a higher degree of exposure to shocks and/or a greater intensity of shocks (either external or environmental shocks). It seems straightforward to expect that an increase in the EVI would raise domestic economic growth volatility. On the other 
hand, there may be a reverse causality from the economic growth volatility indicator to the indicator of EVI, because governments in countries that face a rising level of economic growth volatility because of an increasing in the EVI level may implement policies aiming at reducing the EVI level. the same time, national governments do not have control over all elements of the structural economic vulnerability indicator, which means that the reverse causality would not apply to all components of EVI. Specifically, national governments have practically almost no control over the occurrence and frequency (and hence size) of external or environmental shocks. Additionally, not all sub-components of the exposure to shocks may be affected by the level of economic growth volatility in a given country. To recall (see Appendix1), the components of the sub-index of exposure to shocks are the population size, the remoteness from world markets, the degree of export product concentration, the share of population living in low elevated coastal zone, and the share of agriculture, forestry and fishery in GDP. Among these factors, national governments have no control over the country's remoteness from world markets, and eventually (at least in the short run) over the population size and the share of population living in low elevated coastal zone. However, they can reduce (over the medium to long term) the share of agriculture, forestry and fishery in GDP, and influence the level of export product concentration by implementing policies that would promote the development of high value-added exportable products. Overall, the suspected reverse causality would likely run from economic growth volatility to the sub-indices capturing the share of agriculture, forestry and fishery in GDP, and the level of export product concentration in the indicator "EVI". The two-step system GMM approach would help address this endogeneity concern.

Notwithstanding this, for robustness check analysis, we have also used two other estimators ${ }^{14}$, namely the within fixed effects ("FE") with standard errors being corrected by means of the Driscoll and Kraay (1998) method, and the feasible generalized least squares (FGLS) to estimate the indicator of economic resilience. In so doing, we consider the variable "EVI" as weakly exogenous. The indicators of economic resilience computed based on the two-step system GMM, FE and FGLS estimators are respectively denoted "RESILGMM1", "RESILFE1", and "RESILFGLS1". Lower values of each of these indices indicate greater economic resilience (as they implied lower values of output volatility), while higher values of each these indices reflect lower level of economic resilience.

Finally, it is important to emphasize that as the regression of economic growth volatility on EVI is performed in a panel data setting, the extracted indicator of economic resilience (using any of the estimators mentioned above) is an indicator of 'relative' economic resilience across countries in the full sample, since the mean of the residuals equals zero. As a result, one could argue that the computed indicator of economic resilience would be sensitive to the choice of the sample. This is not, in fact, the case in the present study because the indicator of 'relative' economic resilience has been originally computed using the whole universe of countries for which data is available, over the period 2000-2018.

${ }^{14}$ It is worth noting that the cluster-robust Hausman test proposed by Kaiser (2015) that allows choosing among between the regression based on the random effects and the one based on the fixed effects, shows a p-value higher than 0.10 (i.e., the $10 \%$ level). This indicates that there could be a priori a preference for one estimator over the other, although we may be inclined to opt for the random effects based estimator (here the FGLS approach) given the large dominance of the between-country variation (it amounts to 11.2 in the full sample) over the within-country variation (which amounts to 2.95). 
Having constructed the indicator of economic resilience, we find useful to examine graphically how it has evolved over time, including comparing to the indicator of productive capacities (denoted "PCI"). As noted above, the indicator of productive capacities is developed by the UNCTAD and is the weighted index of eight components (see Appendix 1 for details on the computation of this indicator). Values of "PCI" range between 0 and 100, with higher values indicating higher levels of productive capacities.

Figure 1 presents the evolution of economic resilience and productive capacities over the full sample, and Figure 2 shows the cross-plot between these two variables over the full sample. Note that the two Figures have been constructive using non-overlapping sub-periods ${ }^{15}$ of 3 -year average data for each of the three indicators of economic resilience (i.e., the one based on the twostep system GMM approach). Additionally, Figure 1 is constructed using the indicators "RESILGMM1", "RESILFGLS1" and "RESILFE1", while Figure 2 relies on the indicators "RESILGMM", "RESILFGLS" and "RESILFE", which are nothing else the transformation of respectively "RESILGMM1", "RESILFGLS1" and "RESILFE1" using the method of Yeyati et al. (2007) (see Appendix 1) so as to limit the skewness of the originally computed indicators.

\section{[Insert Figure 1, here]}

We note from Figure 1 that the two indices of economic resilience "RESILFGLS1" and "RESILFE1" have moved in parallel over the full period. To a large extent, the main indicator "RESILGMM1" also evolved in a similar fashion, although with a lower magnitude of fluctuations.

Let us start with the development of the indicator "RESILGMM" over the period. Values of this indicator slightly declined from 0.045 in 2003-2005 to 0.01 2006-2008, which indicates that, on average, countries improved their level of economic resilience between these two sub-periods. The indicator then increased substantially to reach the value 0.3 in 2009-2011, thereby suggesting that countries experienced lower economic resilience over this period. This may be due to the occurrence of the 2008 financial crisis, which might have weakened the economic resilience of developing countries, notably those that were less prepared to cushion the adverse effects of this unexpected crisis. From 2009-2011 to 2015-2018, the indicator "RESILGMM1" exhibited a strong downward trend, as its values substantially declined to reach the value -0.15 in 2015-2018. One interpretation of this development of the economic resilience indicator from 2009-2011 to 20152018 can be that both developed and developing countries drew lessons from 2008 financial crisis, and through greater international cooperation (i.e., with the assistance of regional and international institutions), they adopted adequate measures and policies to reduce the risk of occurrence of future financial shocks, and tried to the extent possible, to bolster their economic resilience to future shocks (e.g., through strengthening public finances, promoting financial stability..etc).

As for the resilience indicators "RESILFGLS1" and "RESILFE1", we observe that countries exhibited lower economic resilience between 2000-2002 and 2003-2005 (as the values of these indicators increased from 2000-2002 to 2003-2005). However, between 2003-2005 and 2006-2008, countries showed, on average, a strengthening of economic resilience (as the values of "RESILFGLS" and "RESILFE" declined). Countries then experienced lower economic resilience between 2006-2008 and 2009-2011. From 2009-2011 to the end of the period (i.e., 2015-2018), countries significantly increased their level of economic resilience as values of the indicators

15 As we will see later in the analysis, these sub-periods are 2000-2002; 2003-2005; 2006-2008; 2009-2011; 2012-2014 and 2015-2018 (the latter covers 4 years). 
RESILFGLS and RESILFE declined significantly. The explanation provided above concerning the development of "RESILGMM" applies here as well.

We note, at the same time, that on average, countries' level of productive capacities exhibited an upward trend over the full period. The average value of the indicator "PCI" consistently increased over the full period, from 24.8 in 2000-2002 to 29.2 in 2015-2018. This development of the indicator "PCI" over the full period suggests that countries endeavoured to strengthen their productive capacities over time, although this 'average' development of PCI over the full sample might hide differentiated developments across countries in the full sample.

\section{[Insert Figure 2, here]}

Figure 2 shows a positive correlation pattern between economic resilience indicators RESILGMM and RESILFE and the indicator of productive capacities over the full sample. This positive correlation pattern does not imply a causality, as many other factors may affect the relationship between productive capacities and economic resilience. Only an equation estimated by an appropriate economic estimator would inform about the genuine direction of the effect of productive capacities on economic resilience. Finally, the correlation pattern between PCI and RESILFGLS is not clear.

\section{Model specification and econometric approach}

This section lays out the model specification that would help investigate empirically the effect of productive capacities on economic resilience (section 5.1). It, then, discusses the theoretical effects of the regressors included in the model (apart from the variable representing the productive capacities) on economic resilience (section 5.2). Finally, it briefly presents the econometric approach used to perform the empirical exercise (section 5.3).

\subsection{Model specification}

Our study is closed in spirit to those of Jolles et al. (2018) and Sondermann (2018), even though these two works have focused respectively on euro area countries and OECD countries, whereas the present study focus es on developing countries. We take cue, to a large extent, from the works by Jolles et al. (2018) and Sondermann (2018), to lay out a model that relates productive capacities to our indicator of economic resilience ${ }^{16}$.

We consider the following dynamic model specification (1):

$$
\begin{aligned}
& \text { RESIL }_{i t}=\beta_{1} \text { RESIL }_{i t-1}+\beta_{2} \text { PCI }_{i t}+\beta_{3} \log (G D P C)_{i t}+\beta_{4} \text { OPEN }_{i t}+\beta_{5} \text { FINPOL }_{i t}+\beta_{6} \text { INFL }_{i t}+ \\
& \beta_{7} \text { FINDEV }_{\text {it }}+\mu_{\mathrm{i}}+\gamma_{\mathrm{t}}+\omega_{\mathrm{it}}
\end{aligned}
$$

Model (1) has been estimated using a sample of 118 developing countries, with data spanning the period 2000-2018. This panel dataset has been constructed on the basis of data availability. As per the practice in the macroeconomic literature, we use sub-periods, in particular non-overlapping sub-periods of 3 -year intervals to dampen the effect of business cycles on the variables. The sub-

${ }^{16}$ We have also drawn some insights from studies on the macroeconomic determinants of economic recovery at the country level (e.g., Barthélémy et al., 2020; Hong and Tornell, 2005; IMF, 2018; 2021; Kannan, 2012; Wise et al., 2015) or regional level (e.g., Brada et al., 2021; Hundt and Holtermann, 2020). 
periods are 2000-2002; 2003-2005; 2006-2008; 2009-2011; 2012-2014 and 2015-2018 (which covers 4 years). The subscripts $i$ and $t$ are respectively associated with a country, and each timeperiod. $\beta_{1}$ to $\beta_{7}$ are parameters that will be estimated. $\mu_{\mathrm{i}}$ are countries' specific effects and $\gamma_{\mathrm{t}}$ are time dummies acting for global shocks that impact together all countries' economic resilience. These time dummies are included in this equation because they were not included in the regression that helped to calculate the economic resilience indicator. $\omega_{i t}$ are random error terms.

The dependent variable "RESIL" is the indicator of economic resilience. It is primarily measured by "RESILGMM", and for robustness check, by the indicators "RESILFGLS" and "RESILFE". Note that as mentioned in Appendix 1, the dependent variable "RESIL" is here the transformation of the originally computed indicator of economic resilience using the method suggested by Yeyati et al. (2007) (see Appendix 1). This is due to the high skewness of the distribution of "RESILGMM1". To recall, the originally computed indicators of economic resilience are denoted "RESILGMM1", "RESILFGLS1" and "RESILFE1".

We have introduced the one-period lag of "RESIL" as a regressor in model (1) with a view to accounting for the possible inertia in countries' level of economic resilience. In fact, there is no reason to believe that the level of economic resilience in period t-1 would not be related to the level of economic resilience in period $t$.

The variable "PCI" represents the indicator of productive capacities, which we defined above. Each of its eight components are denoted "HUMCAP" (human capital), "ENERG" (energy infrastructure), "TRANSP" (transport infrastructure), "ICT" (information and communication technologies), "INST" (institutional and governance quality), "PRIVATE" (private sector) "SCI" (structural change in production) and "NATCAP" (natural capital). The values of each subcomponent of "PCI" range between 0 and 100, with higher values indicating an improvement in the indicator in question.

Th control variables "GDPC", "OPEN", "FINPOL", and "FINDEV" are respectively the real per capita income (which is a proxy for the development level), the trade openness level, the degree of capital account openness, and the overall depth of financial development. The natural logarithm has been applied to the real per capita income variable to reduce the high skewness of its distribution. The regressor "INFL" is the transformed measure of the inflation rate, also by the method of Yeyati et al. (2007) (see Appendix 1) - so as to reduce the skewed distribution of the inflation rate. The description of variables contained in model (1) (and all variables that will be used later in the analysis) along with their source are provided in Appendix 1. We also present in Appendix 2 the descriptive statistics on all these variables, and Appendix 3 contains the list of countries contained in the full sample.

\subsection{Theoretical effects of variables in model (1) on economic resilience}

We now discuss the theoretical expected effect of each regressor in model (1).

\section{Effect of the real per capita income}

We expect the real per capita income - which provides an indication of a country's development level - to influence positively economic resilience. This is because a high real per capita income may reflect greater economic sophistication, and hence a greater capacity of countries in question to weather shocks. Wealthier countries usually have much more resources (e.g., human and financial resources) to manage the fallout of crises than less developed countries do. 


\section{Effect of inflation on economic resilience}

Low and stable inflation rates reflect the stance of monetary and fiscal policies, in particular prudent monetary policies, and contained fiscal deficits (e.g., Catão and Terrones, 2005; Zhang and Dai, 2019). Lower inflation rates, therefore, provide an indication of a stable macroeconomic environment, which could help countries enhance their economic resilience. Countries with low and stable inflation rate can withstand shocks without excessive welfare costs (e.g., Briguglio et al., 2009). We expect lower inflation to be associated with greater economic resilience.

\section{Effect of Trade openness on economic resilience}

As the COVID-19 pandemic erupted and escalated, some analysts (e.g., Shih, 2020) called for rethinking the shape of global value chains, and in this regard, expressed the view that some countries, including those where firms' resilience become weaken because of their reliance on few suppliers, should start exploring ways to reduce their reliance on international supply chains so as to build more resilient economies. In contrast, other analysts put forth the insurance role of global value chains as well as their capacity to bolster economic resilience during the pandemic (e.g., National Board of Trade Sweden, 2020). Baldwin and Evenett (2020) have called for maintaining economies open to international trade, as this would help health Ministries source their imports from a wide range of suppliers during the pandemic. Meyer et al. (2020) has argued that disruptions of supply chains in early 2020 were of a temporary nature, and Miroudot (2020) has stated that solutions being proposed were not consistent with the conclusions of the supply chain literature, where reshoring did not lead to resilience. He has, therefore, suggested that it would be wise to identify the concrete issues faced by firms during the crisis and the policies that can solve them, before redesigning global supply chains. He has subsequently discussed policies that can build resilience at the firm and global levels, and the appropriate narrative to reshape the debate on the policy implications of COVID-19 for global supply chains.

The literature on the relationship between trade openness and economic resilience has provided, on the one hand, that greater trade openness can expose countries to shocks, and hence increase their vulnerability to external shocks (e.g., Bekaert and Harvey, 1997, 2000; Montalbano, 2011), and result in higher output volatility. This is particularly the case for countries with a high degree of trade specialization, including on low value-added products (e.g., Di Giovanni and Levchenko, 2009; 2014; Haddad et al., 2013; $\mathrm{Kim}^{17}$ et al., 2016; Loayza et al., 2007) or when there is a high degree of global financial uncertainty (e.g., Bonciani and Ricci, 2020). In this scenario, it is clear that greater trade openness, including through lower trade barriers, would be associated with lower economic resilience. On the other hand, a higher level of trade openness and the associated low trade barriers may not affect developing countries' size of shocks, and may even reduce their size of exposure to shocks (e.g, Gnangnon, 2016; Montalbano, 2011). As a result, trade openness could lead to lower output volatility when countries diversify their export product baskets or their economic structure (e.g., Balavac et al., 2016; Calderón ${ }^{18}$ et al., 2005; Calderón and

$17 \mathrm{Kim}$ et al. (2016) have found that greater international trade dampens economic fluctuations in the short-run, but raises it in the long-run.

18 Calderón et al. (2005) have obtained empirically that trade openness limits the adverse effect of trade related shocks on growth volatility. 
Schmidt-Hebbel, 2008; Haddad et al., 2013). In this context, trade openness can be associated with a higher level of economic resilience.

On another note, trade openness can enhance competition, and may foster innovation by reducing the search of monopoly rents and incentivizing incumbent firms to improve their innovation performance, for example thanks to their interaction with more knowledgeable foreign buyers (Aghion et al. 1997, 2005). Trade openness can also facilitate the diffusion of knowledge, and the transfer of technology ${ }^{19}$ if it allows importing firms to improve their 'domestic' technology by incorporating into their production processes the (eventually non-available in the domestic market) technology embedded in the imported capital goods or inputs (e.g., Grossman and Helpman, 1991, 2015). Through its effect on innovation (and technology adoption), trade openness can contribute to fostering economic resilience in light of the possible positive effect of innovation on economic resilience (see Section 2). In a nutshell, it is difficult to anticipate the direction of the effect of trade openness on economic resilience, and only the empirical analysis could provide guidance on this.

\section{Effect of Financial openness on economic resilience}

Financial openness (i.e., capital account openness) can foster economic resilience by allowing firms and economic agents to diversify the risks they faced (e.g., idiosyncratic national risks) and to have access to funding at lower costs in the international markets. These would help firms and even economic agents to easily withstand shocks, and resist the adverse effects of negative shocks. Indeed, financial openness provides opportunities for firms to expand the range of financial instruments to which they can have access, and hence allow them to better diversify risks and improve the efficiency in resources allocation (e.g., Acemoglu and Zilibotti, 1997; Obstfeld, 1994; Reese and Weisbach, 2002). It also enables access to more liquidity, and helps to obtain funding at lower capital costs and longer maturities compared to funding from domestic markets (e.g., Ball et al., 2018; Schmukler and Vesperoni, 2006; Stulz, 1999; Turk Ariss, 2016). Additionally, financial openness can result in a higher level of economic resilience if it leads to lower output volatility. A number of studies have shown evidence that financial openness can be associated with lower output volatility, especially in the context of a high depth of domestic financial development (e.g., Ahmed and Suardi, 2009; Calderón and Schmidt-Hebbel, 2008), when the domestic financial system is not in the transitional turmoil (Calderón et al., 2005) or in the context of global financial uncertainty (e.g., Bonciani and Ricci, 2020). Meanwhile, greater financial openness can also amplify financial distortions that may outweigh its benefits (e.g., Eichengreen and Leblang, 2003). This would particularly be the case if the openness of the capital account enhanced competition in the domestic financial sector such that local banks become adversely affected by the financial policies (this is the case in poor countries - Claessens and Huizinga, 2001). In this context, financial openness would ultimately be associated with greater economic instability (e.g., Agénor, 2003; Summers, 2000; Wei, 2018).

Overall, the direction of the effect of financial openness on economic resilience is a priori indetermined, and remains would be determined empirically.

${ }_{19}$ Caselli and Coleman (2001), Comin and Hobijn (2004) and Coelli et al. (2016) have uncovered a positive effect of trade openness on technology adoption. 


\section{Effect of Financial development on economic resilience}

An important body of the literature has showed that a well-working financial system can play a key role in fostering economic growth and development (e.g., Beck et al. 2000; King and Levine, 1993; Levine and Zervos, 1998; Schumpeter, 1911). In the presence of shocks, well-functioning domestic financial markets can help smooth out consumption and investment (e.g., Gertler et al. 2009; Islam and Maitra, 2012; Jack and Suri, 2014; Kinnan and Townsend, 2012; Somville and Vandewalle, 2019). For example, Gertler et al. (2009) have provided empirical support for the argument that access to micro-financial savings and lending institutions has helped Indonesian families to self-insure consumption against health shocks. In the same vein, the work by Islam and Maitra (2012) has shown that households in rural Bangladesh fairly well insured against health shocks thanks to their access to microcredit. Access to microcredit by these households prevented them from selling livestock so as to insure consumption in the event of health shocks. These findings are slightly different from the message conveyed by many other studies (e.g., Besley, 1995; Fafchamps et al. 1998; Gertler and Gruber, 2002), whereby wealthier households had usually been able to insure against income shocks in general and, in particular health illness shocks. Kinnan and Townsend (2012) have explored which type of networks (i.e., kinship and financial) mattered most for smoothing consumption and investment in the face of income volatility in Thailand and Indonesia. They have found that access to financial institutions was helpful in smoothing consumption, whereas kinship networks were not helpful. Jack and Suri (2014) have demonstrated how the mobile technology, in particular the mobile money and its associated reduction in transaction costs in Kenya, helped households insure against fall in consumption when hit by a negative shock. In fact, they have obtained empirical evidence that when households in Kenya faced a negative shock, the consumption of households that used a mobile money was not affected, while households that did not use a mobile money experienced a decline of their consumption by 7 per cent. These effects materialized through increases in remittances received and the diversity of senders.

Somville and Vandewalle (2019) have documented empirically that rural Indian households that had access to a bank account were able to smooth consumption much better (thanks to procyclical saving) than those that did not have a bank account. The authors concluded on the importance of the role of banking in low and middle-income countries. Xue (2020) have reported a negative effect of financial development on aggregate growth volatility in the global perspective, although the size of the negative effect is smaller for developing countries than for advanced countries. Pomeroy et al. (2020) contended that financial inclusion (i.e., access to formal financial services) can help to improve economic resilience by reducing the different vulnerabilities faced by poor fishing households and rural communities.

Against this background, we could be tempted to postulate that a well-functioning domestic financial sector could help bolster economic resilience. However, existing financial vulnerabilities in the financial system can threat the stability of the financial system and limit the ability of the domestic financial markets to play their role of smoothing consumption and investment in the face of shocks. Such vulnerabilities are the under-pricing of (measured) risk and the associated excessive leverage, maturity and currency mismatches, as well as the interconnectedness and common exposures of the financial sector that can make individual financial institutions systematically important (e.g., Caldera Sánchez and Röhn, 2016). The existing of these vulnerabilities, if not appropriately addressed, would result in lower economic resilience. 
Finally, financial development may not lead to greater economic resilience if it results in higher output volatility. The empirical evidence on the effect of financial development on output volatility is mixed. For example, Beck et al. (2006) have obtained that well-developed financial intermediaries dampen (magnify) the effect of real sector shocks (monetary shocks) on output fluctuations. Wang et al. (2018) uncovered that by facilitating better credit allocations, well developed financial markets tend to lead to lower aggregate volatility. Ibrahima and Alagidede (2017) have found for subSaharan African countries that while well-developed domestic financial markets help dampen economic volatility, monetary shocks appeared to have large positive effects on economic volatility, in contrast with real shocks that had large negative effects on economic volatility. The authors have also looked at the effect of financial development on the components of economic volatility. Financial development mitigates the effect of real shocks, while magnifying the effect of monetary shocks on the components of volatility. The dampening effects are larger only in the short run.

Summing-up, the direction of the effect of financial development on economic resilience is a prior unknown, and will be determined only empirically.

\subsection{Econometric approach}

We now discuss the econometric approach(es) used to estimate model (1) or other specifications of this model described below.

We commence the empirical analysis by estimating a static specification of model (1), that is, model (1) that excludes the lagged dependent variable as regressor, and where "RESIL" is measured by "RESILGMM", and for robustness check, by "RESILFGLS" and "RESILFE". The purpose of doing so is to examine how productive capacities affect economic resilience in a static form of model (1). The estimation is performed using the FE and FGLS estimators, and results are reported in Table 1. It is noteworthy that in this static specification of model (1), all regressors have been introduced with a one period lag in order to mitigate the possible endogeneity concern, in particular the reverse causality from the dependent variable to each regressor in model (1).

The use of the one period lag of regressors in the static form of model (1) might not fully address the endogeneity problems highlighted above. Additionally, one might not be fully convinced by the reliance only on the static specification of model (1) to derive the conclusion of the analysis. This is because the absence of the one-period lag of the dependent variable in the model to account for the eventual state dependence path in the level of economic resilience may result in biased estimates. In other words, relying on the static form of model (1) may lead to a misspecification of the model if the one-period lag of the dependent variable were revealed to be highly important. At the same time, the presence of the lag of the dependent variable in model (1) is likely to raise another endogeneity problem if in its dynamic form, model (1) was estimated using the FE or FGLS approaches (or alternatively the pooled ordinary least squares estimator). This is because of the correlation between the lagged dependent variable and countries' specific (time invariant) effects, which leads to biased estimates, notably in panel datasets with small time dimension and large cross-sections (this is Nickell bias - see Nickell, 1981).

To tackle all endogeneity concerns raised above in the dynamic model (1), we use the twostep system GMM estimator (already described above). We report the outcomes of the tests that help to evaluate the validity of this estimator, while also avoiding over-instrumentation by ensuring that the number of instruments is lower than the number of countries in the regressions. We 
consider all regressors as endogenous due to the potential bi-directional causality between the dependent variable and each of these regressors. The rationale for this is as follows. While the improvement of productive capacities is expected to influence economic resilience, it is also possible that the level of economic resilience may incentivize countries to foster their productive capacities. For example, countries with a weak economic resilience may make efforts to enhance their productive capacities so as to reduce their exposure to shocks, and be able to withstand easily adverse shocks that would occur. Also, countries that have a low level of economic resilience and that wish to strengthen it may be inclined to reduce their levels of trade openness and financial openness if they realize that the latter exposes them to external shocks, and weakens their economic resilience to future shocks. However, if these countries' open up to international trade and capital flows brings more benefits than it generates costs, they will likely further open-up their economies to trade and capital flows so as to enhance their economic resilience. The level of economic resilience (in particular if it is low) can also affect the willingness of countries to adopt policies (e.g., fiscal, monetary and financial policies) that would help achieve greater macroeconomic stability. Finally, countries with a low degree of economic resilience, and that wish to foster it may endeavour to develop their domestic financial markets as well as appropriate regulations that would ensure greater financial stability.

We use the two-step system GMM estimator to estimate a number of specifications of the dynamic model (1).

The first specification of model (1) is, in fact, model (1) itself (i.e., in its dynamic form), including with each of three indicators of economic resilience, given that our primary indicator of economic resilience is "RESILGMM" and the other two indicators are used for robustness check analysis. The outcomes of these estimations are displayed in Table 2.

From now onwards, all specifications of model (1) described below rely solely on the indicator "RESILGMM" as the measure of the dependent variable "RESIL".

The second specification of model (1) is the one that allows investigating whether there is a differentiated effect of productive capacities on economic resilience in LDCs versus NonLDCs within the full sample. To that end, we estimate a variant of model (1), that is, model (1) in which we add the dummy "LDC" that represents LDCs, and its interaction with the variable "PCI". The dummy "LDC" takes the value "1" for LDCs, and "0", otherwise. The list of LDCs used in the analysis is presented in Appendix 3, and the results of this estimation are presented in column [1] of Table 3.

The third variant of model (1) allows exploring how, more generally, productive capacities affect economic resilience across countries in the full sample. This variant of model (1) takes the form of model (1) that includes the interaction between the variable "PCI" and the real per capita income. The estimates arising from the estimation of this variant of model (1) are reported in column [2] of Table 2.

Table 4 contains outcomes stemming from the estimation of various oth er specification of model (1) that help to examine the effect of each of the components of the index of productive capacities on economic resilience. These different specifications of model (1) are in fact model (1) in which we introduce (once) each of the above-mentioned eight components of "PCI". 


\section{Interpretation of empirical Results}

We note across all six columns of Table 1 that the coefficients of "PCI" are negative. They are significant at the $1 \%$ level in all columns, except for column [3] where the significance is only at the $5 \%$ level. However, the magnitudes of these coefficients are not the same across the six columns of the Table. These outcomes suggest that developing productive capacities in period t1 influences positively economic resilience in period $t$ in developing countries. With regard to control variables, it appears that across the six columns of the Table, the real per capita income holds coefficients thar are positive and significant at the $1 \%$ level, thereby indicating that countries with a higher real per capita income have a lower level of economic resilience than countries with a lower real per capita income. This finding runs in contrast with our theoretical expectation, but it may eventually hide the fact that the effect of the real per capita income on economic resilience is dependent on the level of productive capacities (or eventually other variables included in the model). Trade openness tends to exert a positive effect on economic resilience, but only for results based on the FGLS approach, notably the ones in columns [4] and [6] of the Table. Greater liberalization of the capital account influences negatively and significantly economic resilience, but only for results based on the FE approach (as for the FGLS-based outcomes, there is no significant effect of capital account openness on economic resilience). A rise in the inflation rate (which reflects a higher macroeconomic instability) exerts a negative and significant effect on economic resilience (see only the FE-based results, as there is no significant effect of inflation on economic resilience for the FGLS-based outcomes). Finally, in all columns but column [5] of Table 1, deepening financial development induces a lower level of economic resilience.

\section{[Insert Table 1, here]}

As pointed out above, these outcomes should be taken with caution, given the endogeneity concerns raised above.

We now consider results presented in Tables 2 to 4, which are based on the two-step system GMM estimator. We first note that in all columns of the three Tables, all conditions for the validity of this estimator are met. Indeed, the p-values of the $\operatorname{AR}(1)$ and $\operatorname{AR}(2)$ tests show that we cannot reject the null hypothesis of each of these tests. Additionally, the p-values related to the overidentifying restrictions test are higher than the $10 \%$ level of statistical significance, thereby suggesting the joint validity of instrumental variables. Finally, we notice that in all columns of Tables 2 to 4, the lagged dependent variable holds a positive and significant coefficient at least at the $5 \%$ level. This confirms the inertia in the dependent variable, and indicates that a lower level of economic resilience in period t -1 is associated with greater economic resilience in period t. Based on all these outcomes, we conclude that the two-system GMM estimator is appropriate to perform the empirical analysis.

\section{[Insert Table 2, here]}

Turning to our key variable of interest, we find that across the three columns of Table 2 , the coefficients of "PCI" are yet different but negative and significant at the $1 \%$ level. Therefore, we can conclude that the enhancement of productive capacities leads to greater economic resilience. Specifically, results based on our main indicator of economic resilience, namely "RESILGMM" (see column [1] of Table 2), we conclude that a 1-point increase in the index of productive capacities raises economic resilience by 0.3 point. For the indicators "RESILFGLS" and "RESILFE" as dependent variable, we obtain that a 1-point increase in the index of productive 
capacities raises economic resilience respectively by 0.7 and 0.6 point. Turning to column [1], we obtain for control variables that the real per capita income exerts a negative and significant effect (at the 1\% level) on economic resilience. While once again, this outcome does not reflect our theoretical expectation, the interpretation provided just above applies here as well. The coefficient of the trade openness variable is negative and significant at the $1 \%$ level, and indicates that greater trade openness improves the level of economic resilience. At the same time, greater financial openness is negatively associated with economic resilience (as the coefficient of the financial openness indicator is positive and significant at the $1 \%$ level). This finding may indicate that the financial distortions associated with greater liberalization of the capital account outweigh the positive effects that it would bring to developing countries, notably in terms of output volatility, and hence economic resilience. Higher inflation rates erode economic resilience, as the coefficient of the inflation variable is positive and significant at the $1 \%$ level. Finally, we obtain that greater financial development exerts no significant on economic resilience. Note that the outcomes concerning control variables in all columns of Tables 3 and 4 align, to a large extent, with those in column [1] of Table 2.

\section{[Insert Table 3, here]}

Outcomes reported in column [1] of Table 3 show a positive and significant coefficient (at the $1 \%$ level) of the interaction variable ["PCI*LDC"]. This suggests that the positive effect of productive capacities on economic resilience is higher in NonLDCs than in LDCs. This is consistent with our argument above that the positive coefficient of the real per capita income in column [1] of Table 2 might reflect the fact that the effect of the real per capita income on productive capacities is dependent upon the level of productive capacities. As the coefficient of "PCI" in column [1] of Table 3 is negative and also significant at the 1\% level, we conclude that the net effect of productive capacities on economic resilience in LDCs and NonLDCs is given respectively by $-0.013(=-0.0472+0.0338)$ and -0.047 .

As for estimates presented in column [2] of Table 3, we find that the interaction term related to the variable "(PCI* $[\log (\mathrm{GDPC})])$ " is negative and significant at the $1 \%$ level, while the estimate associated with "PCI" is yet positive, but significant only at the $10 \%$ level. These outcomes confirm once again our argument put forth above that the effect of the real per capita income on economic resilience is genuinely dependent on countries' level of productive capacities. At the $1 \%$ level, productive capacities consistently lead to a higher level of economic resilience as the level of the real per capita income rises. In other words, countries with a higher level of real per capita income enjoy a higher degree of economic resilience than relatively less developed countries.

\section{[Insert Table 4, here]}

Results in Table 4 suggest that among the components of the overall productive capacities index, five components hold a significant coefficient at the conventional significance levels (in particular here at least at the $5 \%$ level). Additionally, all these significant coefficients are negative. These components are human capital, energy infrastructure, transport infrastructure, information communication technologies, and the institutional and governance quality. Specially, human capital development, the development of energy and transport infrastructure, the promotion of access to ICT tools, and an improvement in the institutional and governance quality are all associated with greater economic resilience. At the same time, natural resources, the development of the private sector, and structural change in production do not exert a significant impact on economic resilience in developing countries. 
Overall, results in Tables 2 to 4 convey the message that greater productive capacities are associated with a higher level of economic resilience. Additionally, this positive effect of productive capacities on economic resilience is higher in more advanced developing countries than in relatively less advanced developing countries such as LDCs. Finally, the above-mentioned positive effect of productive capacities on economic resilience is essentially driven by human capital development, the development of energy and transport infrastructure, the promotion of ICT tools, and a better institutional and governance quality.

\section{Does development aid influence the effect of productive capacities on economic resilience?}

It is well known that many developing countries are dependent on development aid - the socalled foreign aid or overall development assistance - for financing their development needs. Given the nature of the components of development aid and the components of productive capacities, it is highly likely that development aid might have significantly contributed to enhancing productive capacities in developing countries. The present section aims to examine whether the effect of productive capacities on economic resilience depends on the amount of development aid received by countries.

By simply looking at the components of development aid, one can expect development aid to contribute to enhancing productive capacities in recipient countries. For the purpose of the present analysis, we decompose the overall development aid into two major categories, namely Aid for Trade (AfT), and NonAfT, which represents all other parts of the overall development aid that are not classified as AfT flows. The category of AfT within the total development aid (ODA) enveloped was created further to the adoption of the AfT Initiative by the WTO Members at the Hong Kong Ministerial Declaration (W'TO, 2005). The objective of this Initiative is to help developing countries, particularly LDCs to build the supply-side capacity and trade-related infrastructure that they need to implement and benefit from W'TO Agreements. According to the OECD, the AfT category comprises three major components: AfT for economic infrastructure ("AfTINFRA"), which includes transport and storage, communications, and energy generation and supply; AfT for building productive capacity ("AfTPROD") whose components are banking and financial services, business and other services, agriculture, forestry, fishing, industry, mineral resources and mining, and tourism; and AfT related to trade policy and regulations ("AfTPOL"). The latter includes trade policy and regulations and trade-related adjustment. The other types of ODA (i.e., NonAfT) category include for example humanitarian aid, aid for education, and aid for health. Note that total ODA flows (denoted "ODA") is the sum of total AfT flows and total NonAfT flows.

In a forthcoming paper, Gnangnon $(2021)^{20}$ has discussed theoretically the effect of both AfT flows and NonAfT flows on productive capacities, and obtained empirically that both types of aid flows influence positively productive capacities in developing countries. Therefore, one can expect development aid flows to affect the influence of productive capacities on economic resilience.

${ }^{20}$ We refer the readers to the forthcoming paper by Gnangnon (2021) for the discussion on the effect of development aid, including AfT flows and NonAfT flows on productive capacities in developing countries. We do not intend to provide here this theoretical discussion, as such a discussion is already contained in the forthcoming paper by Gnangnon (2021). The paper would be made available online soon. 
To address empirically the question as to whether the effect of productive capacities on economic resilience depends on the amount of development aid that accrued to countries, we commence by estimating a variant of model (1) that includes the variable "ODA". The purpose of doing so is to check whether the statistical significance of the variable "PCI" is sensitive to the inclusion of the total development aid flows variable in the model. In principle, if the effect of developmentaid on economic resilience works essentially through the productive capacity channel, then the coefficient of either "PCI" or "ODA" in the estimated model should be statistically nonsignificant at the conventional significance levels, while the coefficient of the other variable would be statistically significant at the conventional significance levels. The outcomes of the estimation of this variant of model (1) are reported in column [1] of Table 5.

Next, we estimate another specification of model (1) that includes the interaction between the index of overall productive capacities and the total ODA flows variable. This specification of model (1) helps to address our main question, i.e., whether the effect of the overall productive capacities on economic resilience depends on the total ODA flows received by countries. The outcomes of this estimation are reported in column [2] of Table 5.

We then move on to consider the extent to which the effect of productive capacities on economic resilience depends on each of the two main components of total ODA, namely total AfT flows and total NonAfT flows. This assessment is performed by estimating another form of model (1) that incorporates both the variables representing total AfT flows and total NonAfT flows, besides their respective interaction with the index of the overall productive capacities. The outcomes of the estimation of this model are presented in column [3] of Table 5. It is worth noting at this stage of the analysis that these results remain unchanged when we estimated the same specification of model (1) but separately for total AfT flows along with its interaction with the index of the overall productive capacities, and for total NonAfT flows along with its interaction with the index of the overall productive capacities.

Finally, we push the analysis forward by examining how each component of the variable capturing the total AfT flows matters for the effect of productive capacities on economic resilience. To address this issue, we simply estimate three different other specifications of model (1) that include the interaction between the index of the overall productive capacities with each of the three components of the variable capturing total AfT flows, which is introduced once in the relevant model. In all these three variants of model (1), we control for both the variable representing the total NonAfT flows and its interaction with the index of productive capacities. The estimates arising from the estimation of each of these three variants of model (1) are presented in columns [4] to [6] of Table 5.

\section{[Insert Table 5, here]}

Let us now interpret all estimates reported in Table 5. We first note that the conditions for the validity of the two-step system GMM estimator are met (see the bottom of all columns of Table 5). Moreover, we obtain, once again, that across all columns of this Table, that the indicator of economic resilience exhibits a state dependence path. Taking up the estimates themselves, we find that in column [1], total development aid exerts no significant effect on economic resilience, while the variable "PCI" holds a negative and significant coefficient at the 5\% level. Therefore, it seems that in this specification of model (1), the indicator of productive capacities have absorbed the effect of total development aid on economic resilience, which may signify that the effect of productive capacities on economic resilience may genuinely work through the development aid 
channel. This is confirmed by the estimates presented in column [3] of the Table, where the coefficient of the interaction variable ["PCI* $\log (\mathrm{ODA})$ "] is positive and significant at the $1 \%$ level, while both variables "PCI" and "ODA" have negative and significant coefficients at the $1 \%$ level. Based on these outcomes, we can deduce that the effect of productive capacities on economic resilience depends on the amount of total development aid that countries received. It, however, appears that the lower the amount of development aid, the higher the positive effect of productive capacities on economic resilience. In other words, productive capacities tend to increase economic resilience in countries that receive low amounts of total development aid, and the lower these amounts, the greater is the magnitude of the positive effect of productive capacities on economic resilience. The turning point of total development aid (amount) above which productive capacities lead to lower economic resilience is US $\$$ million 3,013 [ = exponential $(0.251 / 0.0115)]$ (note that values of "ODA" in the full sample range between US\$290000 and US\$ million 5,850 - see Appendix 2). Another interpretation of the outcomes is that development aid induces greater economic resilience in countries with low levels of the overall productive capacities. This meant that by helping to enhance productive capacities in countries that suffer from low levels of productive capacities, development aid would help to improve the level of economic resilience in these countries.

\section{[Insert Figure 3, here]}

We illustrate graphically these findings by plotting in Figure 3, at the 95 per cent confidence intervals, how the marginal effect of productive capacities on economic resilience evolves for different amounts of total development aid. It appears from this Figure that this marginal impact increases as the values of total ODA flows rise, although it is always negative (i.e., it always affects positively economic resilience, but the magnitude of this positive effect diminishes as the amount of total aid rises). However, this marginal impact is not significant for values of total development aid flows higher than US\$ million 444.8. As a consequence, countries that received a total amount of development aid lower than US\$ million 444.8 experience a positive effect of productive capacities on economic resilience, and the lower the amount of development aid, the higher the size of the positive effect of productive capacities on economic resilience.

The key message conveyed by these findings is that development aid is effective in enhancing economic resilience if it were provided to countries with low levels of productive capacities.

Estimates in column [3] of Table 5 show that the pattern observed in Figure 3 concerning the effect of productive capacities on economic resilience reflects opposite directions of the effect of productive capacities on economic resilience for varying levels of AfT flows versus NonAfT flows. In fact, we note from this column of the Table that both the coefficient of "PCI" and the interaction term of the variable ("PCI* $\left[\log (\text { AfTTOT) }]^{*}\right)$ are negative and significant at the $1 \%$

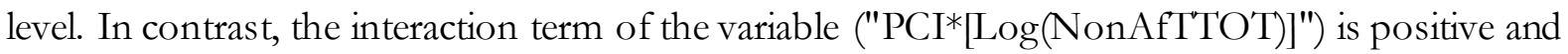
significant at the $1 \%$ level. We conclude that the effects of productive capacities on economic resilience depends on both the amount of total AfT flows, and NonAfT flows. On the one hand, productive capacities always exert a positive effect on economic resilience (i.e., regardless of the amount of total AfT flows), but the magnitude of this positive effect consistently increases as the amount of total AfT flows rises. On the other hand, the effect of productive capacities on economic resilience changes sign when total NonAfT flows exceeds the amount of US\$79675.3 [ = exponential $(0.237 / 0.0210)]$. As this amount is lower than the minimum value of total NonAfT flows in the full sample (values of the variable "NonAfTTOT" range between US\$ 4133839 and 
US\$ billion 5.15), we definitely conclude that strengthening productive capacities always results in lower levels of economic resilience, but the magnitude of this negative effect diminishes for lower amounts of total NonAfT flows. These findings in column [3] of Table 5 certainly explains the outcomes in column [2] of Table 5 concerning the effect of productive capacities on economic resilience for varying amounts of total ODA.

We present in Figures 4 and 5, at the 95 per cent confidence intervals, the development of the marginal effect of productive capacities on economic resilience respectively for varying amounts of total AfT flows and total NonAfT flows. Both Figures confirm the findings above that the effect of productive capacities on economic resilience depends on both AfT flows and NonAfT flows. However, the patterns of these marginal effects move in the opposite direction. In particular, Figure 4 shows that the magnitude of the positive economic resilience effect of productive capacities rises as the amount of total AfT flows increases. This finding highlights the criticality of the overall package of AfT flows in enhancing the positive effect of productive capacities on economic resilience. On the other side, Figure 5 indicates that the magnitude of the negative effect of productive capacities on economic resilience becomes lower as the amount of total NonAfT flows falls.

\section{[Insert Figure 4, here] [Insert Figure 5, here]}

Summing-up, AfT flows contribute to enhancing the positive economic resilience effect of productive capacities, while NonAfT flows tend to hinder the effect of productive capacities on economic resilience. At this stage of the analysis, we could not identify among the components of total NonAfT flows, which ones (if any at all) may have contributed to enhancing the positive influence of productive capacities on economic resilience, and which ones may have worked in the opposite direction. This can be an interesting topic for future research. Meanwhile, given the direct matching between the majority of the components of total AfT flows and some components of the index of overall productive capacities, we find useful to deepen the analysis by investigating how each of the components of total AfT flows matters for the effect of productive capacities on economic resilience.

We note from all columns [4] to [6] of Table 5 that the interaction terms related to the variable capturing the interaction between the index of the overall productive capacities and each of the three components of total AfT flows are all negative and significant at the $1 \%$ level. Concurrently, the estimates associated with the index of productive capacities are also negative and significant at the $1 \%$ level. These outcomes confirm the finding in column [3] regarding the economic resilience effect of productive capacities for different amounts of total AfT flows. We conclude that the development of productive capacities always leads to greater economic resilience, and the size of this positive effect increases as the amount of each of the components of total AfT variable (including AfT for economic infrastructure, AfT for productive capacities, and AfT for trade policy and regulation) rises. These findings, one again, confirm the relevance of greater amounts of AfT flows in particular for developing countries that have low levels of productive capacities if donor-countries were to help them to bolstering economic resilience through the strengthening of productive capacities in recipient-countries. 


\section{Further analysis}

This section deepens the previous analysis regarding the effect of productive capacities on economic resilience by investigating whether this effect depends on countries' economic characteristics, that is, the level of trade openness, the degree of capital account openness, the inflation rate, and the depth of financial development. In performing this empirical analysis, the present section aims to build on the theoretical discussion provided above (in section 2) so as to provide an insight into how productive capacities interact with the countries' economic features in affecting economic resilience.

We undertake this empirical exercise by estimating several variants of model (1) that include for each, an interaction between the index of productive capacities and each of the four control variables in model (1). Thus, we start by estimating a specification of model (1) that includes the interaction between the index of productive capacities and the trade openness variable. The outcomes of the estimation of this model specification are presented in column [1] of Table 6. However, we notice from a graphical analysis that countries whose trade openness level is higher than 2 (to recall the trade openness indicator is not expressed in percentage) represent outliers in the full sample. These countries are Liberia, Malaysia, Seychelles and Singapore. We, therefore, remove these four countries from the full sample, and re-estimate the specification of model (1) described just above, results of which are reported in column [2] of Table 6.

Second, we estimate another specification of model (1) that contains the interaction between the index of productive capacities and the financial openness variable. The results of this specification of model (1) are displayed in column [3].

Finally, columns [4] and [5] of Table 6 contain estimates arising from the estimation of two different other specifications of model (1): the first one contains the interaction between the index of productive capacities and the inflation rate variable (see results in column [4]), and the second one includes the interaction between the index of productive capacities and the financial development variable (see results in column [5]).

\section{[Insert Table 6, here]}

It is interesting to note that all requirements for the consistency of the two-step system GMM estimator are met, and additionally the coefficients of the lagged dependent variable are positive and significant in all six columns of the Table. Taking up the estimates in column [1] of the Table, we find that the coefficient of the interaction between the index of productive capacities and trade openness is not significant at the conventional significance levels. However, the es timates in column [2] of the same Table show that this coefficient becomes negative and significant at the $1 \%$ level., whereas at the same time, the coefficient of "PCI" is not significant at the $10 \%$ level. These outcomes suggest that outliers have driven estimates in column [1], which show the absence of a statistically significant joint effect of productive capacities and trade openness on economic resilience. However, based on estimates in column [2], we conclude that the productive capacities further enhance economic resilience as countries improve their level of openness to international trade, that is, the higher the level of trade openness, the higher is the magnitude of the positive effect of productive capacities on economic resilience. These findings suggest that the possible positive effects of trade openness outweigh its possible negative effects (see section 5) in driving the positive effect of productive capacities on economic resilience. Similar findings are observed for the joint effect of productive capacities and financial openness on economic resilience (see 
column [3] of Table 6). Results in this column show a negative and significant coefficient (at the $1 \%$ level) of the interaction term, and a significant coefficient of "PCI", but only at the $10 \%$ level. We conclude that at the $5 \%$ level, the greater the level of financial openness, the higher is the positive contribution of productive capacities to the enhancement of economic resilience. Likewise, we obtain from column [4] of Table 6 that the effect of productive capacities on economic resilience depends on the prevailing inflation rate in the country concerned. This is because both the coefficient of "PCI" and the interaction term of "(PCI*INFL)" are significant at the $1 \%$ level, with the former being negative, and the latter being positive. It follows that the lower the inflation rate, the greater is the size of the positive effect of productive capacities on economic resilience. Finally, as per results in column [5] of Table 6, there is no joint effect of productive capacities and financial development on economic resilience, that is, the effect of productive capacities on economic resilience does not depend on the financial development depth. This is because the coefficient of the interaction variable ("PCI*FINDEV") is not significant at the conventional significance levels, while the coefficient of "PCI" is negative and significant at the $1 \%$ level.

In a nutshell, Table 6 conveys a number of key messages. Productive capacities contribute significantly to fostering economic resilience in developing countries that experience greater trade openness, greater financial openness, and lower inflation rates. However, the depth of financial development does not appear to influence the effect of productive capacities on economic resilience in developing countries.

\section{Conclusion}

This paper investigates the effect of productive capacities on economic resilience in developing countries. This analysis is particularly timely because the issue as to how to build or strengthen economic resilience, particularly in developing countries, would be at the heart of the core of policy discussion both in the short and medium terms. Yet, in light of their experience with the 2008 financial crisis and the recent COVID-19 pandemic, developed countries also need to strengthen their economic resilience to future shocks. However, these countries have much more resources (both human and financial resources, including easier access to international financial markets to borrow during adverse shocks) than developing countries to cope with negative shocks that affect their economies. And, the reality is that the frequency and size of shocks faced by developing countries is higher than the ones by developed countries, notably for external shocks (i.e., for example economic and financial shocks that originate in developed countries such as the 2008 financial crisis and the current COVID-9 outbreak) that usually affect disproportionately developing countries.

The present analysis develops an indicator of economic resilience in developing countries, and makes use of the indicator of productive capacities recently developed by the UNCTAD to undertake the empirical analysis. Findings are quite interesting and show that the development of productive capacities is associated with greater economic resilience in developing countries. These positive effects are particularly enhanced in countries that further open-up their economies to both international trade and capital flows, as well as those that strive to maintain a stable macroeconomic environment. Interestingly, development aid, notably AfT flows appear to 
enhance the positive effect of productive capacities on economic resilience. However, productive capacities lead to lower levels of economic resilience as countries receive higher NonAfT inflows.

These outcomes have several policy implications. Development aid remains essential for helping developing countries to foster their economic resilience to shocks through the development of productive capacities. A particular attention should be devoted to AfT flows, which in principle, target projects that directly contribute to the enhancement of productive capacities in recipient-countries and are, therefore, less fungible than the other development aid flows, i.e., NonAfT flows. The analysis shows that AfT flows should be provided to the neediest developing countries, for example the poorest ones, i.e., LDCs, as the latter exhibit the lowest levels of productive capacities. This implies that donor-countries should scale up AfT flows in favour to developing countries, including LDCs, but they should work together with recipient economies to make such aid more predictable so as to allow it to achieve its intended purposes. Efforts should also be made by recipient-countries' governments to ensure that NonAfT flows do not disrupt recipient economies, and ultimately hinder their capacity to use these capital inflows to develop their productive capacities.

At the same time, to ensure, policymakers in developing countries should also implement policies that enhance the positive effect of productive capacities on economic resilience. These policies involve ensuring a stable macroeconomic environment. promoting greater trade and financial openness.

As highlighted by Guillaumont (2017), like any other computed indicator, our indicator of economic resilience certainly has some limitations. Future research could involve trying to address the limitations of our economic resilience indicator, and possibly build developing indicators of economic resilience, such as the one built on the basis of the reaction of social indicators to exogenous shocks and income volatility, as suggested by Guillaumont (2017). 


\section{$\underline{\text { References }}$}

Aarstad, J., and Kvitastein, O. A. (2020). An unexpected external shock and enterprises' innovation performance. Applied Economics Letters, DOI: 10.1080/13504851.2020.1814942

Acemoglu, D., and Zilibotti, F. (1997). Was prometheus unbound by chance? Risk, diversification, and growth. Journal of Political Economy, 105(4), 709-51.

Acemoglu, D., Egorov, G., and Sonin, K. (2020). Institutional Change and Institutional Persistence. NBER Working Paper 27852. National Bureau of Economic Research, Cambridge, USA.

Acemoglu, D., Johnson, S., Robinson, J., and Taicharoen, Y. (2003). Institutional causes, macroeconomic symptoms: volatility, crises and growth. Journal of Monetary Economics, 50(1), $49-123$.

Agénor, P-R. (2003). Benefits and Costs of International Financial Integration: Theory and Facts. World Economy, 26(8), 1089-1118.

Aghion, P., Akcigit, U., and Howitt, P. (2015). The Schumpeterian Growth Paradigm. Annual Review of Economics, 7(1), 557-575.

Aghion, P., Bloom, N., Blundell, R., Griffith, R. and Howitt, P. (2005). Competition and Innovation: An Inverted-U Relationship. The Quarterly Journal of Economics, 120(2), 701-728.

Aghion, P., Bloom, N., Blundell, R., Griffith, R., and Howitt, P. (2005). Competition and innovation: An inverted u relationship. Quarterly Journal of Economics, 102(2), 701-728.

Aghion, P., Farhi, E., and Kharroubi, E. (2019). Monetary Policy, Product Market Competition and Growth. Economica, 86(343), 431-470.

Aghion, P., Harris, C., and Vickers, J. (1997). Competition and growth with step-by-step innovation: An example. European Economic Review 41(3-5), 771-782.

Agüero, J.M., Balcázar, C.F., Maldonado, S., and Ñopo, H. (2021). The value of redistribution: Natural resources and the formation of human capital under weak institutions. Journal of Development Economics, 148, 102581, https://doi.org/10.1016/i.jdeveco.2020.102581

Aguiar, M., and Gopinath, G. (2007). Emerging Markets Business Cycles: The Cycle is the Trend. Journal of Political Economy, 115(1), 11-69.

Ahmed, A.D., and Suardi, S. (2009). Macroeconomic Volatility, Trade and Financial Liberalization in Africa. World Development, 37(10), 1623-1636.

Alfani, F., Dabalen, A., Fisker, P., and Molini, V. (2015). Can We Measure Resilience? A Proposed Method and Evidence from Countries in the Sahel. Policy Research Working Paper WPS7170, World Bank, Washington, D.C. 
Álvarez, L. J., and Hernando, I. (2007). "Competition and Price Adjustment in the Euro Area", Chapter 13, In 'Pricing Decisions in the Euro Area: How Firms Set Prices and Why', Edited by Fabiani, S., Loupias, C.S., Martins, F. M. M., and Sabbatini, R., Published by Oxford University Press Scholarship Online, DOI: 10.1093/acprof:oso/9780195309287.001.0001 - September 2007.

Anderton, R., Di Lupidio, B., and Jarmulska, B. (2020). The impact of product market regulation on productivity through firm churning: Evidence from European countries. Economic Modelling, 91, 487-501.

Andrews, D., and Saia, A. (2017). Coping with Creative Destruction: Reducing the Costs of Firm Exit. OECD Economics Department Working Papers No. 1353. OECD Publishing, OECD, Paris.

Ariss, R. T. (2016). Legal Systems, Capital Structure, and Debt Maturity in Developing Countries. Corporate Governance, 24(2), 130-144.

Arrow, K. (1962). "Economic Welfare and the Allocation of Resources for Invention." In The Rate and Direction of Inventive Activity: Economic and Social Factors, 609-626.

Atkins, J., Mazzi, S., and Easter, C. (2000). A Commonwealth Vulnerability Index for Developing Countries: The Position of Small States. Economic Paper No. 40. London: Commonwealth Secretariat.

Atolia, M., Loungani, P., Marquis, M., and Papageorgiou, C. (2020). Rethinking development policy: What remains of structural transformation? World Development, 128, 104834.

Bahadur, A., and Doczi, J. (2016). Unlocking resilience through autonomous innovation. ODI Working paper. Overseas Development Institute, London, United Kingdom.

Balavac, M., and Pugh, G. (2016). The link between trade openness, export diversification, institutions and output volatility in transition countries. Economic Systems, 40(2), 273-287.

Balavac, M., and Pugh, G. (2016). The link between trade openness, export diversification, institutions and output volatility in transition countries. Economic Systems, 40(2), 273-287.

Baldwin, R., and Evenett, S.J. (2020). "Introduction" in Richard Baldwin and Simon J. Evenett (eds.), Covid-10 and Trade Policy: Why Turning Inward Won't Work, CEPR Press VoxEU.org eBook, 2020.

Ball, R., Hail, L., and Vasvari, F. (2018). Equity Cross-Listings in the U.S. and the Price of Debt. Review of Accounting Studies, 23(2), 385-421.

Barrot, L.D., Calderón, C., and Servén, L. (2018). Openness, specialization, and the external vulnerability of developing countries. Journal of Development Economics, 134, 310-328.

Barthélémy, S., Binet, M-E., and Pentecôte, J-S. (2020). Worldwide economic recoveries from financial crises through the decades. Journal of International Money and Finance, 105, 102204.

Bas, M. (2020). The effect of communication and energy services reform on manufacturing firms' innovation. Journal of Comparative Economics, 48(2), 339-362. 
Bassanini, A., and Duval, R. (2007). The determinants of unemployment across OECD countries: Reassessing the role of policies and institutions. OECD Economic Studies, Vol. 2006/1.

Beath, A., Christia, F., and Ruben, E. (2012). Winning hearts and minds through development? Evidence from a field experiment in Afghanistan. World Bank Policy Research Working Paper Series 6129, The World Bank, Washington, D.C.

Bekaert, G., Harvey, C.R. and Lundblad, C. (2006). Growth Volatility and Financial Liberalization. Journal of International Money and Finance, 25(3), 370-403.

Beck, T., Levine, R., and Loayza, N. (2000). Finance and the sources of growth. Journal of Financial Economics, 58(1-2), 261-300.

Beck, T., Lundberg, M., and Majnoni, G. (2006). Financial intermediary development and growth volatility: Do intermediaries dampen or magnify shocks? Journal of International Money and Finance, 25(7), 1146-1167.

Bekaert, G., and Harvey, C. (1997). Emerging equity market volatility. Journal of financial economics, 43, 29-77.

Bekaert, G., and Harvey, C.R. (2000). Foreign speculators and emerging equity markets. Journal of Finance, 55, 565-614.

Berche, B., von Ferber, C. Holovatch, T., and Holovatch, Yu. (2009). Resilience of public transport networks against attacks. The European Physical Journal B, 71, 125-137.

Bermpei, T., Kalyvas, A., and Nguyen, T.C. (2018). Does institutional quality condition the effect of bank regulations and supervision on bank stability? Evidence from emerging and developing economies. International Review of Financial Analysis, 59, 255-275.

Besley, T. (1995). Nonmarket institutions for credit and risk sharing in low-income countries. Journal of Economic Perspectives, 9(3), 115-127.

Blundell, R., and Bond, S. (1998). Initial Conditions and Moment Restrictions in Dynamic Panel Data Models. Journal of Econometrics, 87(1), 115-143.

Bonciani, D., and Ricci, M. (2020). The international effects of global financial uncertainty shocks. Journal of International Money and Finance, 109, 102236.

Boschma, R. (2015). Towards an evolutionary perspective on regional resilience. Regional Studies, 49(5), 733-751.

Boulanouar, Z., Alqahtani, F., and Hamdi, B. (2021). Bank ownership, institutional quality and financial stability: evidence from the GCC region. Pacific-Basin Finance Journal, 66, 101510.

Bowen, A., Cochrane, S. and Fankhauser, S. (2012). Climate change, adaptation and economic growth. Climatic Change, 113, 95-106. 
Brada, J.C., Gajewski, P., and Kutan, A. M. (2021). Economic resiliency and recovery, lessons from the financial crisis for the COVID-19 pandemic: A regional perspective from Central and Eastem Europe. International Review of Financial Analysis, 74, 101658.

Briguglio, L. (1995). Small Island States and their Economic Vulnerabilities. World Development, 23(9), 1615-32.

Briguglio, L. (2004). Economic vulnerability and resilience: concepts and measurements. In Briguglio, L. \& Kisanga, E. J. (Eds.), Economic Vulnerability and Resilience of Small States: Malta: Islands and Small States Institute of the University of Malta, London: Commonwealth Secretariat.

Briguglio, L., and E. J. Kisanga (eds) (2004). Vulnerability and Resilience of Small States. Malta: Commonwealth Secretariat and Islands and Small States Institute of the University of Malta.

Briguglio, L., and Galea, W. (2003). Updating the Economic Vulnerability Index Occasional Chapters on Islands and Small States. Malta: Islands and Small States Institute of the University of Malta.

Briguglio, L., Cordina, G., Farrugia, N., and Vella, S. (2006). Conceptualising and measuring economic resilience. In L. Briguglio, G. Cordina, \& E.J. Kisanga (Eds.), Building the economic resilience of small states (pp. 265-287). Blata I-Bajda: Formatek Ltd.

Briguglio, L., Cordina, G., Farrugia, N., and Vella, S. (2009). Economic Vulnerability and Resilience: Concepts and Measurements. Oxford Development Studies, 37(3), 229-247.

Briguglio, L.P. (2016). Exposure to external shocks and economic resilience of countries: evidence from global indicators", Journal of Economic Studies, 43(6), 1057-1078.

Bristow, G., and Healy, A. (2014). Regional resilience: an agency perspective. Regional Studies, 48(5), 923-935.

Bristow, G., and Healy, A. (2015) Crisis response, choice and resilience: insights from complexity thinking. Cambridge Journal of Regions Economy and Society, 8(2), 241-256.

Bristow, G., and Healy, A. (2018). Innovation and regional economic resilience: an exploratory analysis. The Annals of Regional Science, 60, 265-284.

Bristow, G., and Healy, A. (2020). (Eds.) Handbook on Regional Economic Resilience; Edward Elgar Publishing: Cheltenham, UK.

Caldera Sánchez, A. and Röhn, O. (2016). How do policies influence GDP tail risks?”, OECD Economics Department Working Papers ECO/WKP (2016) 63, OECD Publishing, Paris.

Calderón, C., and Schmidt-Hebbel, K. (2008). Openness and Growth Volatility. Working Papers Central Bank of Chile $\mathrm{N}^{\circ} 483$, Central Bank of Chile, Chile.

Calderón, C.A., Loayza, N., and Klaus, S-H. (2005). Does Openness Imply Greater Exposure? World Bank Policy Research Working Paper No. 3733. World Bank, Washington, D.C. 
Cappelli, R., Montobbio, F., and Morrison, A. (2021). Unemployment resistance across EU regions: the role of technological and human capital. Journal of Evolutionary Economics, 31, 147 178.

Caselli, F., and Coleman, W. II (2001). Cross-country technology diffusion: the case of computers. American Economic Review, 91(2), 328-335.

Catão, L.A.V., and Terrones, M.E. (2005). Fiscal deficits and inflation. Journal of Monetary Economics, 52(3), 529-554.

Chacon-Hurtado, D., Kumar, I., Gkritza, K., Fricker, J.D., Beaulieu, L.J. (2020). The role of transportation accessibility in regional economic resilience. Journal of Transport Geography, 84, 102695.

Chenaf-Nicet, D. (2020). Dynamics of Structural Change in a Globalized World: What Is the Role Played by Institutions in the Case of Sub-Saharan African Countries? The European Journal of Development Research, 32, 998-1037.

Chinn, M. D. and Ito, H. (2006). What Matters for Financial Development? Capital Controls, Institutions, and Interactions. Journal of Development Economics, 81(1), 163-192.

Chiu, S.-H., Lin, T.-Y., and Yang, H.-L. (2020). Measuring Energy Performance for Regional Sustainable Development in China: A New Framework based on a Dynamic Two-Stage SBM Approach. Sustainability, 12(7), 2851 (pages 1-15).

Chou, T. (2012). Does Development Assistance Reduce Violence? Evidence from Afghanistan'. Economics of Peace and Security Journal, 79(2), 5-13.

Claessens, S.-K.A., and Huizinga, H. (2001). How does foreign entry affect domestic banking markets? Journal of Banking and Finance, 25(5), 891-911.

Coelli, F., Moxnes, A., and Ulltveit-Moe, K.H. (2016). Better, Faster, Stronger: Global Innovation and Trade Liberalization. The Review of Economics and Statistics, 1-42. https://doi.org/10.1162/rest a 00951

Comin, D., and Hobijn, B. (2004) Cross-country technology adoption: making the theories face the facts. Journal of Monetary Economics, 51(1), 39-83.

Cordina, G. (2004a). 'Economic Vulnerability, Resilience and Capital Formation'. In L. Briguglio and E. J. Kisanga (eds), Economic Vulnerability and Resilience of Small States. Malta: Islands and Small States Institute and London: Commonwealth Secretariat.

Cordina, G. (2004b). 'Economic Vulnerability and Economic Growth: Some Results from a NeoClassical Growth Modelling Approach'. Journal of Economic Development, 29(2), 21-39.

Dabla-Norris, E., and Gündüz, Y. B. (2014). Exogenous Shocks and Growth Crises in LowIncome Countries: A Vulnerability Index. World Development, 59, 360-378.

Dao, M.Q. (2017). Determinants of the global financial crisis recovery: an empirical assessment. Journal of Economic Studies, 44(1), 36-46. 
Davies, A., and Tonts, M. (2010). Economic diversity and regional socio-economic Performance. Geographical Research, 48, 223-234.

Di Caro, P., and Fratesi, U. (2018). Regional determinants of economic resilience. Annals of Regional Science, 60, 235-240.

Di Giovanni, J., and Levchenko, A. (2009). Country Size, International Trade, and Aggregate Fluctuations in Granular Economies. Journal of Political Economy, 120(6), 1083-1132.

Di Giovanni, J., and Levchenko, A. (2009). Trade Openness and Volatility. Review of Economics and Statistics, 91(3), 558-585.

Diao, X., Kweka, J., and McMillan, M. (2018). Small firms, structural change and labor productivity growth in Africa: Evidence from Tanzania. World Development, 105, 400-415.

Driscoll, J. C., and Kraay, A.C. (1998). Consistent Covariance Matrix Estimation with Spatially Dependent Panel Data. Review of Economics and Statistics, 80(4), 549-560.

Duval, R., and Furceri, D. (2018). The Effects of Labor and Product Market Reforms: The Role of Macroeconomic Conditions and Policies. IMF Economic Review, 66, 31-69.

Ebeke, C., and Ehrhart, H. (2012). Tax Revenue Instability in Sub-Saharan Africa: Consequences and Remedies. Journal of African Economies, 21(1), 1-27.

Eichengreen, B., and Leblang, D. (2003). Capital Account Liberalization and Growth: Was Mr. Mahathir Right?. International Journal of Finance and Economics, 8(3), 205-224.

Encontre, P. (1999). The Vulnerability and Resilience of Small Island Developing States in the Context of Globalization. Natural Resources Forum, 23(3), 261-70.

Fafchamps, M., Udry, C., and Czukas, K. (1998). Drought and saving in West Africa: are livestock a buffer stock? Journal of Development Economics, 55(2), 273-305.

Faha, D. R. N. (2021). Revisiting natural resources-conflict nexus. Resources Policy, 70, 101903.

Fall, F., Pisu, M., Pareliussen, J., and Bloch, D. (2014). Vulnerability of Social Institutions: Lessons from the Recent Crisis and Historical Episodes. OECD Economics Department Working Papers, No. 1130, OECD Publishing, Paris.

Farrugia, G., and Plutowski, R.W. (2021). Innovation Lessons From the COVID-19 Pandemic. Perspective and Controversy, 95(8), 1574-1577.

Feindouno, S., and Goujon, M. (2016). The retrospective economic vulnerability index, 2015 update. Working paper $n^{\circ} 147$, Fondation pour les Etudes et Recherches sur le Developpement InternationaL (FERDI), Clermont-Ferrand, France.

Fried, S., and Lagakos, D. (2021). Rural electrification, migration and structural transformation: Evidence from Ethiopia. Regional Science and Urban Economics, Available online on 4 February 2021, 103625, https://doi.org/10.1016/i.regsciurbeco.2020.103625 
Furceri, D., and Zdzienicka, A. (2012). How costly are debt crises? Journal of International Money and Finance, 31(4), 726-742.

Geroski, P. (1992). Price Dynamics in UK Manufacturing: A Microeconomic View. Economica, 59, 403-419.

Gertler, P., and Gruber, J. (2002). Insuring consumption against illness. American Economic Review, 92(1), 51-76.

Gertler, P., Levine, D.I., and Moretti, E. (2009). Do microfinance programs help families insure consumption against illness? Health Economics, 18(3), 257-273.

Ghosh, S. (2013). The economics and politics of output volatility: evidence from Indian states. International Review of Applied Economics, 27(1), 110-134.

Gnangnon, S.K (2013). Structural vulnerability and excessive public indebtedness in CFA Franc Zone countries. Economic Modelling, 35, 816-832.

Gnangnon, S.K (2014). Does structural economic vulnerability matter for public indebtedness in developing countries? Journal of Economic Studies, 41(5), 644-671.

Gnangnon, S.K. (2016). Trade openness and structural vulnerability in developing countries. Journal of Economic Studies, 43(1), 70-89.

Gnangnon, S.K (2017). Structural economic vulnerability, openness and bilateral development aid flows. Economic Analysis and Policy, 53, 77-95.

Gnangnon, S. K. (2018). Aid for trade and trade policy in recipient countries. The International Trade Journal, 32(5), 439-464.

Gnangnon, S.K. (2019a). Multilateral trade liberalization and developing countries' economic exposure to shocks. Journal of Economic Studies, 46(2), 496-515.

Gnangnon, S.K. (2019b). Structural economic vulnerability and public revenue performance. International Journal of Public Policy, 15(3/4), 225-247.

Gnangnon, S.K. (2019c). Does Aid for Information and Communications Technology Help Reduce the Global Digital Divide? Policy \& Internet, 11(3), 344-369.

Gnangnon, S. K. (2021). Effect of development aid on productive capacities in developing countries. Forthcoming paper, May 2021.

Gnangnon, S.K and Iyer, H. (2017). Structural Economic Vulnerability, Trade Policy and FDI Inflows. Journal of International Commerce, Economics and Policy, 08 (01), 1750005.

Grossman, G., and Helpman, E. (1991). Innovation and Growth in the World Economy (Cambridge: MIT Press).

Grossman, GM, and Helpman, E. (2015). Globalization and growth. American Economic Review, 105(5), 100-104. 
Guillaumont, P. (2004). 'On the Economic Vulnerability of Low-Income Countries'. In L. Briguglio and E. J. Kisanga (eds), Economic Vulnerability and Resilience of Small States. Malta: Formatek Malta, 54-71.

Guillaumont, P. (2009). An Economic Vulnerability Index: Its Design and Use for International Development Policy. Oxford Development Studies, 37(3), 193-228.

Guillaumont, P. (2010). Assessing the Economic Vulnerability of Small Island Developing States and the Least Developed Countries, The Journal of Development Studies, 46(3), 828-854.

Guillaumont, P. (2015). Measuring Structural Economic Vulnerability in Africa. In ' The Oxford Handbook of Africa and Economics: Volume 1: Context and Concepts', Edited by Monga, C., and Lin, J.Y., Oxford University Press, United Kingdom.

Guillaumont, P. (2017). Vulnerability and Resilience: A Conceptual Framework Applied to Three Asian Countries - Bhutan, Maldives, and Nepal. ADB South Asia Working Paper No. 53, Asian Development Bank, Philippines.

Guillaumont, P., and Wagner, L. (2012). Aid and Growth Accelerations: Vulnerability Matters. UNU-WIDER Working Paper Series WP-2012-031, UNU World Institute for Development Economics Research (UNU-WIDER), Helsinki, Finland.

Gupta, P., Mishra, D., and Sahay, R. (2007). Behavior of output during currency crises. Journal of International Economics, 72 (2), 428-450.

Haddad, M., Lim, J. J., Pancaro, C., and Saborowski, C. (2013). Trade openness reduces growth volatility when countries are well diversified. Canadian Journal of Economics, 46(2), 765-790.

Hallegatte, S. (2014). Economic Resilience - Definition and Measurement. World Bank Policy Research Working Paper, WPS6852. The World Bank, Washington, D.C.

Harjoto, M. A., Rossi, F., Lee, R., and Sergi, B.S. (2020). How do equity markets react to COVID19? Evidence from emerging and developed countries. Journal of Economics and Business, Available online 3 December 2020, 105966, https://doi.org/10.1016/j.jeconbus.2020.105966

Henri, A. O. (2019). Natural resources curse: A reality in Africa. Resources Policy, 63, 101406. Herrendorf, B., Rogerson R., and Valentinyi, A. (2014). Growth and structural transformation. In P. Aghion, and S. Durlauf (Eds.), Handbook of economic growth (vol. 2, pp. 855-941). Amsterdam \& New York: North Holland.

Higón, D.A. (2012). The impact of ICT on innovation activities: Evidence for UK SMEs. International Small Business Journal: Researching Entrepreneurship, 30(6), 684-699

Holling, C. S. (1973). Resilience and Stability of Ecological System. Annual Review of Ecology and Systematics, 4, 1-23.

Hong, K., and Tornell, A. (2005). Recovery from a currency crisis: some stylized facts. Journal of Development Economics, 76(1), 71-96. 
Hundt, C., and Holtermann, L. (2020). The role of national settings in the economic resilience of regions - Evidence from recessionary shocks in Europe from 1990 to 2014. Growth and Change, 51(1), 180-206.

Ibrahima, M., and Alagidede, P. (2017). Financial sector development, economic volatility and shocks in Sub-Saharan Africa. Physica A: Statistical Mechanics and its Applications, 484, 66-81.

IMF (2017). World Economic Outlook: Gaining Momentum? International Monetary Fund, Washington, D.C., April 2017.

IMF (2018). World Economic Outlook: Challenges to Steady Growth. International Monetary Fund, Washington, D.C., October 2018.

IMF (2021). World Economic Outlook: Managing Divergent Recoveries. International Monetary Fund, Washington, D.C., April 2021.

Islam, A., and Maitra, P. (2012). Health shocks and consumption smoothing in rural households: Does microcredit have a role to play? Journal of Development Economics, 97(2), 232-243.

Jack, W., and Suri, T. (2014). Risk sharing and transactions costs: Evidence from Kenya's mobile money revolution. American Economic Review, 104(1), 183-223.

Jiya, A.N., Sama, M.C., and Ouedraogo, I. (2020). Infrastructure, trade openness and economic transformation in Common Market for Eastern and Southern Africa member countries. Social Sciences \& Humanities Open, 2(1), 100072.

Jolles, M., Meyermans, E., and Vasicek, B. (2018). Determinants of economic resilience in the euro area: An empirical assessment of policy levers. Quarterly Report on the Euro Area (QREA), Directorate General Economic and Financial Affairs (DG ECFIN), European Commission, 17(3), $27-46$

Kaiser, B. (2015). RHAUSMAN: Stata module to perform Robust Hausman specification test. Statistical software components S457909. Chestnut Hill, MA: Boston College Department of Economics.

Kannan, P., 2012. Credit conditions and recoveries from financial crises. J. Int. Money Finance 31 (5), 930-947.

Keefe, H. G. (2021). The transmission of global monetary and credit shocks on exchange market pressure in emerging markets and developing economies. Journal of International Financial Markets, Institutions and Money, 72, 101320, https://doi.org/10.1016/i.intfin.2021.101320

Kim, D-H., Lin, S-C., and Suen, Y-B. (2016). Trade, growth and growth volatility: New panel evidence. International Review of Economics \& Finance, 45, 384-399.

King, R. G., and Levine, R. (1993). Finance and growth: Schumpeter might be right. The Quarterly Journal of Economics, 108(3), 717-737.

Kinnan, C., and Townsend, R. (2012). Kinship and financial networks, formal financial access, and risk reduction. The American Economic Review: Papers \& Proceedings, 102(3), 289-293. 
Kolstad, I. (2008). The resource curse: Which institutions matter? Applied Economics Letters, 16(4), 439-442.

Lagravinese, R. (2015). Economic crisis and rising gaps North-South: Evidence from the Italian regions. Cambridge Journal of Regions, Economy and Society, 8(2), 331-342.

Lee, I. H. (2018). Industrial output fluctuations in developing countries: General equilibrium consequences of agricultural productivity shocks. European Economic Review, 102, 240-279.

Levine, R., and Zervos, S. (1998). Stock markets, banks, and economic growth. The American Economic Review, 88(3), 537-58.

Loayza, N.V., Rancière, R., Servén, L., and Ventura, J. (2007). Macroeconomic Volatility and Welfare in Developing Countries: An Introduction. The World Bank Economic Review, 21(3), 343-357.

Martin, R., and Sunley, P. (2015). On the notion of regional economic resilience: conceptualization and explanation, Journal of Economic Geography, 15(1), 1-42.

Martini, B. (2020). Resilience, resistance and recoverability, regional economic structure and human capital in Italy. Are they related? Applied Econometrics and International Development 20(1), 47-62.

Mayunga, J.S. (2007). Understanding and Applying the Concept of Community Disaster Resilience: A Capital-Based Approach', draft working paper prepared for the summer academy, Megacities as Hotspots of Risk: Social Vulnerability and Resilience Building, Munich, Germany, 22-28 July 2007.

McMillan, M., and Verduzco-Gallo, I. (2014). Globalization, Structural Change, and Productivity Growth, with an Update on Africa. World Development, 63, 11-32.

Meierrieks, D. (2021). Weather shocks, climate change and human health. World Development, 138, 105228.

Meyer, B., Mösle, S., and Windisch, M. (2020). Lessons from past disruptions to global value chains. UNIDO Industrial Analytics Platform, May 2020. Retrieved at. https://iap.unido.org/articles/lessons-past-disruptions-global-value-chains

Miroudot, S. (2020). Reshaping the policy debate on the implications of COVID-19 for global supply chains. Journal of International Business Policy, 3, 430-442.

Mirza, N., Hasnaoui, J.A., Naqvi, B. and Rizvi, S.K.A. (2020). The impact of human capital efficiency on Latin American mutual funds during Covid-19 outbreak. Swiss Journal of Economics and Statistics, 156, Article number 16.

Montalbano, P. (2011). Trade Openness and Developing Countries' Vulnerability: Concepts, Misconceptions, and Directions for Research. World Development, 39(9), 1489-1502.

Morck, R., and Nakamura, M. (2018). Japan's ultimately unaccursed natural resources-financed industrialization. Journal of the Japanese and International Economies, 47, 32-54. 
Moro, A. (2012). The Structural Transformation between Manufacturing and Services and the decline in the U.S. GDP Volatility. Review of Economic Dynamics, 15(3), 402-415.

Moro, A. (2015). Structural Change, Growth, and Volatility. American Economic Journal: Macroeconomics, 7(3), 259-294.

Morrison, K. M. (2012). What Can We Learn about the "Resource Curse" from Foreign Aid? The World Bank Research Observer, 27(1), 52-73.

Muhamad, G.M., Heshmati, A., and Khayyat, N. T. (2021). How to reduce the degree of dependency on natural resources? Resources Policy, 72, 102047.

Museru, M., Toerien, F., and Gossel, S. (2014). The impact of aid and public investment volatility on economic growth in sub-Saharan Africa. World Development, 57, 138-147.

National Board of Trade Sweden (2020). Improving Economic Resilience Through Trade - should we rely on our own supply? 51 pages. The National Board of Trade Sweden, Stockholm, Sweden. Retrieved at: https://www.wita.org/atp-research/improving-economic-resilience/

Ngouana, C. A. L. (2013). Structural Transformation and the Volatility of Aggregate Output in OECD Countries. IMF Working Paper WP/13/43, International Monetary Fund, Washington, D.C.

Nickell, S. (1981). Biases in Dynamic Models with Fixed Effects. Econometrica, 49(6), 1417-1426.

Obstfeld, M. (1994). Risk-taking, global diversification and growth. American Economic Review, 84(5), 1310-1329.

OECD (2017). OECD G20 Policy Paper on Economic Resilience and Structural Policies; OECD: Paris, France.

OECD (2020), Development Co-operation Report 2020: Learning from Crises, Building Resilience, OECD Publishing, Paris, https://doi.org/10.1787/f6d42aa5-en

OECD, ADB, UNCDP and ECA (2013). African Economic Outlook 2013: Structural Transformation and Natural Resources, OECD Publishing, Paris.

Olander, P. (2019). Economic Diversification and Institutional Quality-Issues of Concentrated Interests. Studies in Comparative International Development volume 54, 346-364.

Owoundi, J-P. F., Mbassi, C.M., and Owoundi, F. (2021). Does inflation targeting weaken financial stability? Assessing the role of institutional quality. Quarterly Review of Economics and Finance, 80, 374-398.

Oyinlola, M.A., Adedeji, A.A. and Bolarinwa, M.O. (2020). Exploring the nexus among natural resource rents, human capital and industrial development in the SSA region. Economic Change and Restructuring, 53, 87-111.

Park, Y.C., Lee, J.W., 2003. Recovery and sustainability in East Asia. In: Dooley, M., Frankel, J. (Eds.), Managing Currency Crises in Emerging Markets. University of Chicago Press, Chicago. 
Paunov, C., and Planes-Satorra, S. (2021). Science, technology and innovation in the time of COVID-19. OECD Science, Technology and Industry Policy Papers, February 2021, No. 99. OECD, Paris.

Paunov, C., and Rollo, V. (2016). Has the internet fostered inclusive innovation in the Developing World? World Development, 78, 587-609.

Pereira, V., Temouri, Y., and Patel, C. (2020). Exploring the Role and Importance of Human Capital in Resilient High Performing Organisations: Evidence from Business Clusters. Applied Psychology, 69(3), 769-804.

Pomeroy, R., Arango, C., Lomboy, C.G., and Box, S. (2020). Financial inclusion to build economic resilience in small-scale fisheries. Marine Policy, 118, 103982.

Ramalingam, B., and Prabhu, J. (2020). Innovation, development and COVID-19: Challenges, opportunities and ways forward. OECD, Paris, Retrieved at: https://www.oecd.org/coronavirus/policy-responses/innovation-development-and-covid-19challenges-opportunities-and-ways-forward-0c976158/

Reese, W., and Weisbach, M. (2002). Protection of Minority Shareholder Interests, Cross-Lis ting in the United States, and Subsequent Equity Offerings. Journal of Financial Economics, 66(1), 65104.

Robinson, J.A., Torvik, R., and Verdier, T. (2014). Political foundations of the resource curse: A simplification and a comment. Journal of Development Economics, 106, 194-198.

Rodrik, D. (1999). Where Did All the Growth Go? External Shocks, Social Conflict, and Growth Collapses. Journal of Economic Growth, 4(4), 385-412.

Sachs, J.D., and Warner, A.M. (2001). The curse of natural resources. European Economic Review, 45, 827-838.

Sahay, R., Čihák, M., N’Diaye, P., Barajas, A., Bi, R., Ayala, D., Gao, Y., Kyobe, A., Nguyen, L., Saborowski, C., Svirydzenka, K., and Yousefi, S.R. (2015). Rethinking Financial Deepening: Stability and Growth in Emerging Markets. IMF Staff Discussion Note, SDN/15/08, International Monetary Fund, Washington, D.C.

Sánchez, A.C., Rasmussen, M., and Röhn, O. (2016). Economic Resilience: What Role for Policies? Journal of International Commerce, Economics and PolicyVol. 07, No. 02, 1650009.

Schmukler, S. and Vesperoni, E. (2006). Financial Globalization and Debt Maturity in Emerging Economies. Journal of Development Economics, 79(1), 183-207.

Schumpeter, J. A. (1911). A theory of economic development. Cambridge, MA: Harvard University Press.

Schumpeter, J. A. (1994) [1942]. Capitalism, Socialism and Democracy. 5th ed. London: Routledge. Seidu, D., and Maciej, D. (2020). Barriers to Competition in Product Market Regulation: New Insights on Emerging Market and Developing Economies. World Bank, Washington, D.C. 
Shih, W. (2020). Is It Time to Rethink Globalized Supply Chains? MIT Sloan Management Review, 19 March 2020.

Smith, B. (2015). The resource curse exorcised: Evidence from a panel of countries. Journal of Development Economics, 116, 57-73.

Somville, V., and Vandewalle, L. (2019). Access to Banking, Savings and Consumption Smoothing in Rural India. Graduate Institute of International and Development Studies Working Paper No. HEIDWP09-2019, Geneva Switzerland.

Sondermann, D. (2018). Towards more resilient economies: The role of well-functioning economic structures. Journal of Policy Modeling, 40(1), 97-117.

Stulz, R. (1999). Globalization, Corporate Finance and the Cost of Capital. Journal of Applied Corporate Finance, 12(3), 8-25.

Summers, L.H. (2000). International financial crises: causes, prevention, and cures. American Economic Review, 90 (2), 1-16.

Tambo, J.A., and Wünscher, T. (2017). Enhancing resilience to climate shocks through farmer innovation: evidence from northern Ghana. Regional Environmental Change, 17, 1505-1514.

Thorbecke, E., and Pangestu, M. (1998). The Institutional Foundations of Macroeconomic Stability: Indonesia versus Nigeria. In: Hayami Y., Aoki M. (eds) The Institutional Foundations of East Asian Economic Development. International Economic Association Series. Palgrave Macmillan, London. https://doi.org/10.1007/978-1-349-26928-0 5

Udry, C. (1990). Credit markets in Northern Nigeria: credit as insurance in a rural economy. World Bank Economic Review, 4(3), 251-269.

UNCTAD (2006). The Least Developed Countries Report 2006: Developing Productive Capacities. United Nations publication. Sales No. E.06.II.D.9. New York and Geneva.

UNCTAD (2020). The Least Developed Countries Report 2020: Productive Capacities for the New Decade. United Nations publication. Sales No. E.21.II.D.2 New York and Geneva.

United Nations (2016). Global Sustainable Development Report 2016. Department of Economic and Social Affairs, New York.

van der Ploeg, F. (2011). Natural Resources: Curse or Blessing? Journal of Economic Literature, 49(2), 366-420.

Van Eeten, M., Nieuwenhuijs, A., Luiijf, E., Klaver, M., and Cruz, E. (2011). The state and the threat of cascading failure across critical infrastructures: the implications of empirical evidence from media incident reports. Public Administration, 89(2), 381-400.

Wagner, L. (2014). Identifying thresholds in aid effectiveness. Review of World Economics, 150 (3), 619-638. 
Wang, P., Wen, Y., and Xu, Z. (2018). Financial development and long-run volatility trends. Review of Economic Dynamics, 28, 221-251.

Wei, S.J. (2018). Managing financial globalization: insights from the Recent Literature, NBER working paper, No. 24330, Cambridge, MA.

Wise, C., Armijo, L.E. and Katada, S.N. (2015). Unexpected Outcomes: How Emerging Economies Survived the Global Financial Crisis. Brookings Institution Press, Washington, DC.

Woolliscroft, J.O. (2021). Innovation in Response to the COVID-19 Pandemic Crisis. Academic Medicine, 95(8), 1140-1142.

WTO (World Trade Organization) (2005). Ministerial Declaration on Doha Work Programme', WT/MIN(05)/DEC, Adopted on 18 December 2005 at the Sixth Session of Trade Ministers Conference. Ministerial Conference, Hong Kong, China, December 13-18.

Xiaohui, J.T., Hub, X., Hassink, R., and Ni, J. (2020). Industrial structure or agency: What affects regional economic resilience? Evidence from resource-based cities in China. Cities, 106, 102906.

Xue, W-J. (2020). Financial sector development and growth volatility: An international study. International Review of Economics \& Finance, 70, 67-88.

Yohou,D.H., and Goujon, M. (2017). Reassessing Tax Effort in Developing Countries: a Proposal of a Vulnerability-Adjusted Tax Effort Index (VATEI). Working Papers P186, FERDI, ClermontFerrand, France.

Zeev, N.B., and Ifergane, T. (2021). Firing restrictions and economic resilience: Protect and survive? Review of Economic Dynamics, Available online 8 February 2021. In Press, Corrected Proof - https://doi.org/10.1016/j.red.2021.01.003

Zhang, B., and Dai, W. (2019). Trend inflation and macroeconomic stability in a small open economy. Economic Modelling, 91, 769-778 


\section{FIGURES}

Figure 1: Development of productive capacities and economic resilience over the full sample

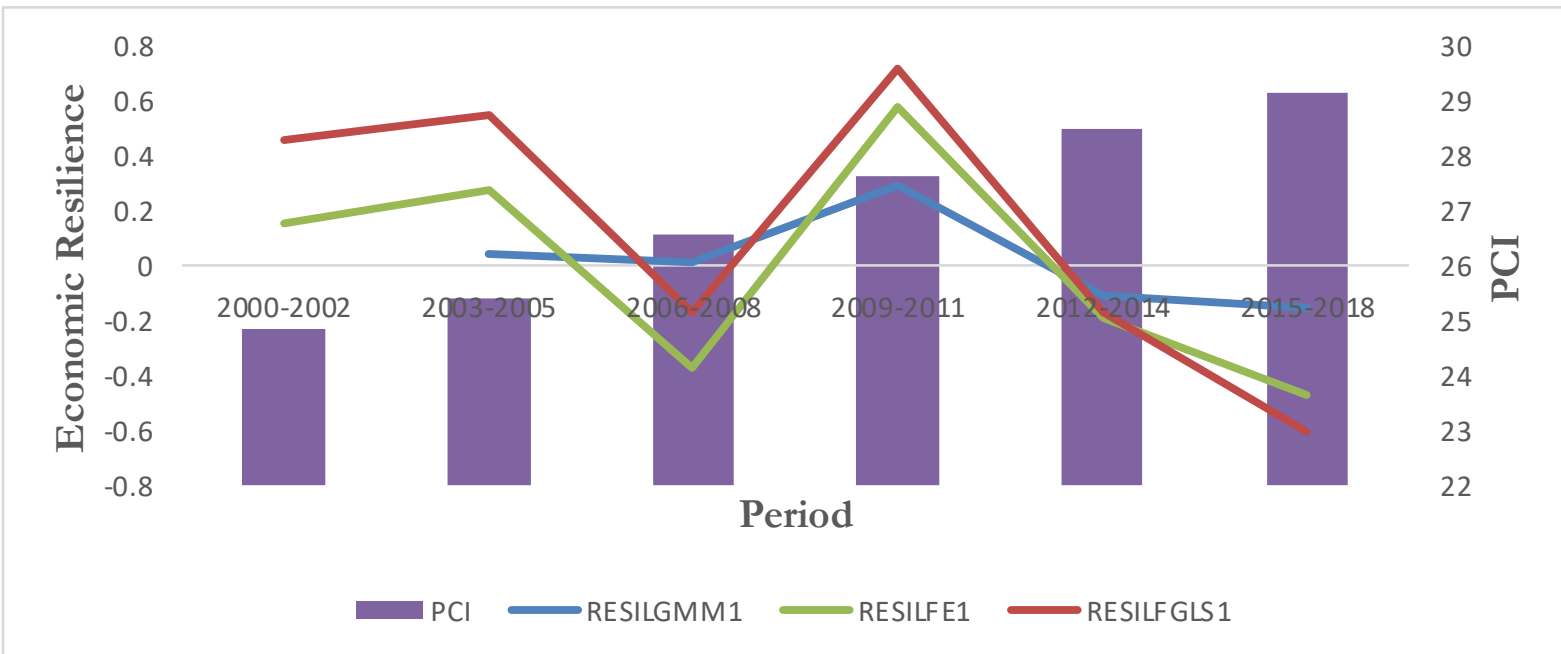

Source: Author

Note: These graphs rely on the original values of the indicators of economic resilience, and not on their transformed values as described in Appendix 1.

Figure 2: Scatter plot between productive capacities and economic resilience over the full sample
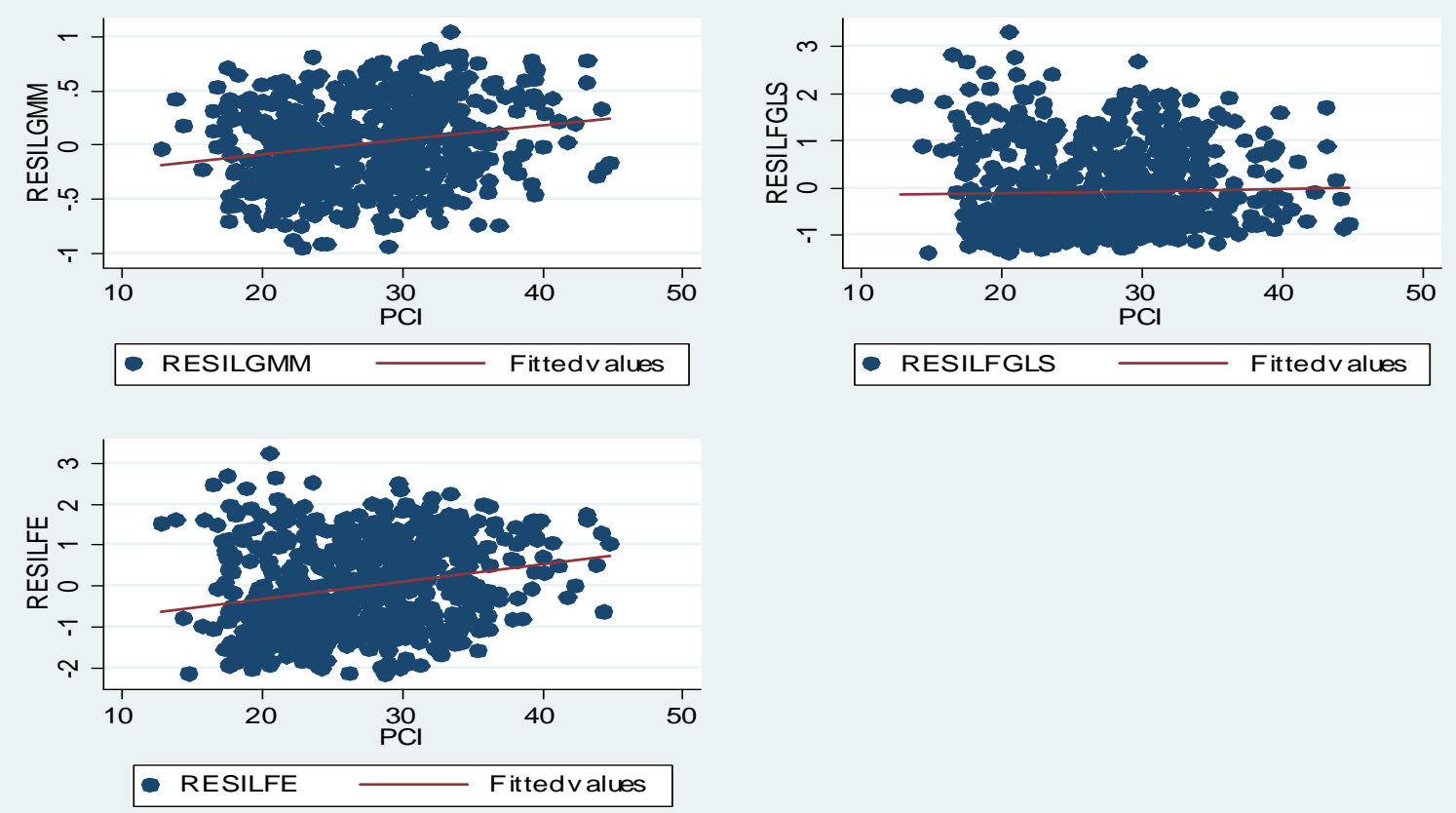

Source: Author

Note: These graphs rely on the transformed values of the indicators of economic resilience, as described in Appendix 1. 
Figure 3: Marginal Impact of "PCI" on "RESILGMM", for varying amounts of total ODA flows

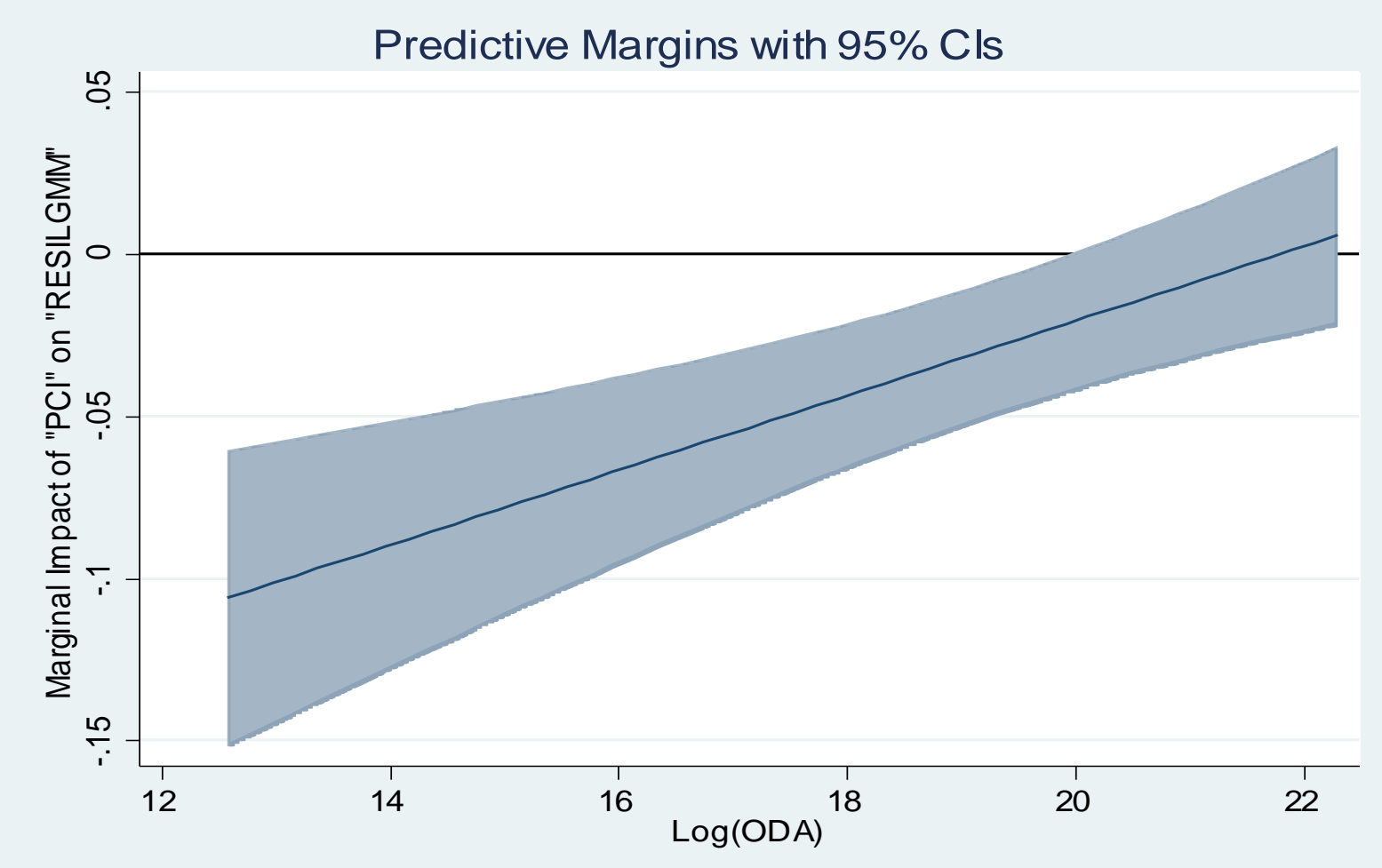

Source: Author

Figure 4: Marginal Impact of "PCI" on "RESILGMM", for varying amounts of total AfT flows

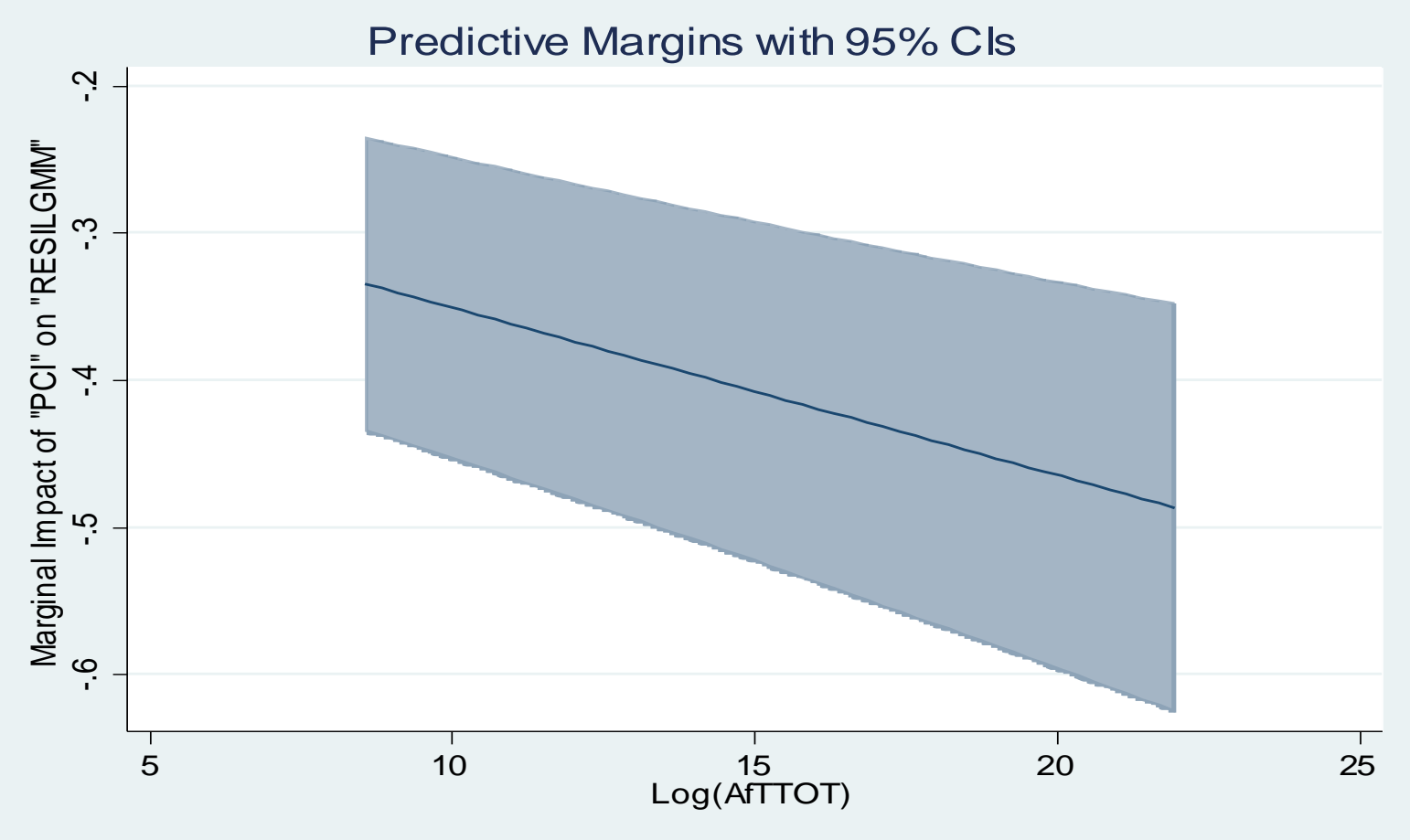

Source: Author 
Figure 5: Marginal Impact of "PCI" on "RESILGMM", for varying amounts of total NonAfT flows

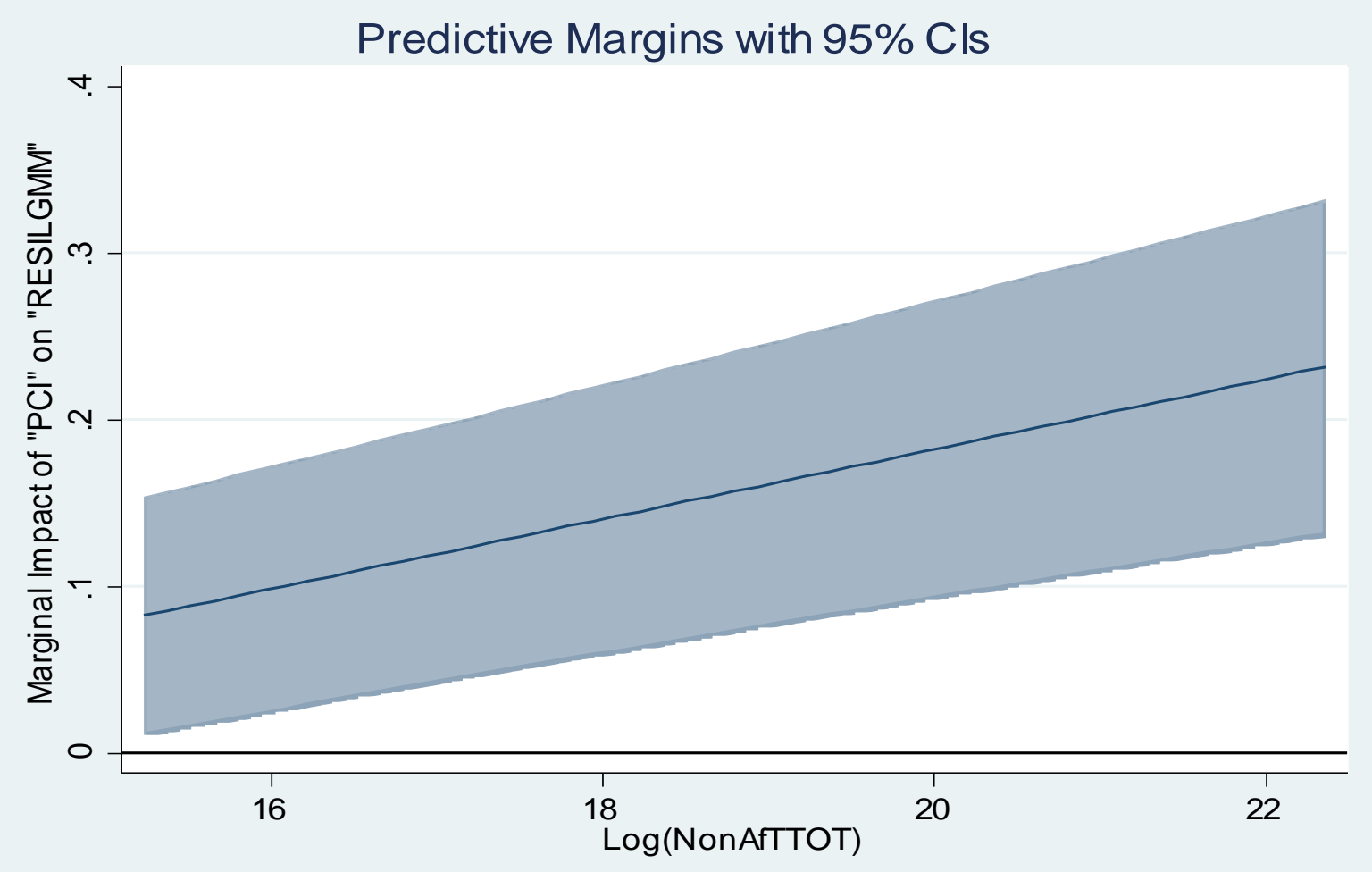

Source: Author 
Table 1: Effect of productive capacities on economic complexity

Estimators: FEDK and FGLS

\begin{tabular}{|c|c|c|c|c|c|c|}
\hline \multirow{2}{*}{ Variables } & \multicolumn{3}{|c|}{ FEDK } & \multicolumn{3}{|c|}{ FGLS } \\
\hline & RESILGMM & RESILFGLS & RESILFE & RESILGMM & RESILFGLS & RESILFE \\
\hline & (1) & (2) & (3) & (4) & (5) & (6) \\
\hline \multirow[t]{2}{*}{$\mathrm{PCI}_{\mathrm{t}-1}$} & $-0.0615^{* * *}$ & $-0.126 * * *$ & $-0.0753 * *$ & $-0.0322 * * *$ & $-0.0662 * * *$ & $-0.104 * * *$ \\
\hline & $(0.0138)$ & $(0.0420)$ & $(0.0328)$ & $(0.00316)$ & $(0.00921)$ & $(0.00819)$ \\
\hline \multirow[t]{2}{*}{$\log (\text { GDPC })_{t-1}$} & $0.247^{* * *}$ & $0.595^{* * *}$ & $0.592^{* * *}$ & $0.193^{* * *}$ & $0.394^{* * *}$ & $0.497 * * *$ \\
\hline & $(0.0660)$ & $(0.162)$ & $(0.144)$ & $(0.00833)$ & $(0.0285)$ & $(0.0298)$ \\
\hline \multirow[t]{2}{*}{$\mathrm{OPEN}_{\mathrm{t}-1}$} & 0.0713 & -0.225 & -0.0525 & $-0.142^{* * *}$ & 0.0857 & $-0.345^{* * *}$ \\
\hline & $(0.0984)$ & $(0.453)$ & $(0.432)$ & $(0.0212)$ & $(0.0556)$ & $(0.0603)$ \\
\hline \multirow[t]{2}{*}{ FINPOL $_{\mathrm{t}-1}$} & $0.288^{* *}$ & $0.441^{* * *}$ & $0.436^{* * *}$ & 0.0146 & -0.0403 & 0.0873 \\
\hline & $(0.124)$ & $(0.149)$ & $(0.105)$ & $(0.0284)$ & $(0.0567)$ & $(0.0535)$ \\
\hline \multirow[t]{2}{*}{$\mathrm{INFL}_{\mathrm{t}-1}$} & $0.0718^{* * *}$ & $0.145^{* * *}$ & $0.139 * * *$ & 0.0131 & 0.0263 & 0.0318 \\
\hline & $(0.0236)$ & $(0.0417)$ & $(0.0350)$ & $(0.0110)$ & $(0.0246)$ & $(0.0287)$ \\
\hline \multirow[t]{2}{*}{ FINDEV $_{\mathrm{t}-1}$} & $0.825^{* *}$ & $2.013^{* * *}$ & $0.977 * * *$ & $0.759 * * *$ & 0.170 & $3.235^{* * *}$ \\
\hline & $(0.318)$ & $(0.572)$ & $(0.347)$ & $(0.0593)$ & $(0.230)$ & $(0.185)$ \\
\hline \multirow[t]{2}{*}{ Constant } & -0.818 & -2.241 & $-3.378 * * *$ & $-0.727 * * *$ & $-1.656 * * *$ & $-1.778 * * *$ \\
\hline & $(0.642)$ & $(1.505)$ & $(1.232)$ & $(0.0586)$ & $(0.178)$ & $(0.152)$ \\
\hline Observations - Countries & $547-118$ & $547-118$ & $547-118$ & $546-117$ & $546-117$ & $546-117$ \\
\hline Within R-squared & 0.0793 & 0.0580 & 0.0377 & & & \\
\hline Pseudo R-squared & & & & 0.5594 & 0.4532 & 0.5764 \\
\hline
\end{tabular}

Note: ${ }^{*} p$-value $<0.1 ;{ }^{* *} p$-value $<0.05$; ${ }^{* * *}$-value $<0.01$. Robust Standard Errors are in parenthesis. The Psendo $\mathrm{R}^{2}$ bas been calculated for FGLS-based regressions, as the correlation coefficient between the dependent variable and its predicted values. Time dummies bave been included in the regressions. 
Table 2: Effect of productive capacities on economic resilience over the full sample Estimator: Two-Step System GMM

\begin{tabular}{|c|c|c|c|}
\hline Variables & RESILGMM & RESILFGLS & RESILFE \\
\hline & $\mathbf{( 1 )}$ & $\mathbf{( 2 )}$ & $\mathbf{( 3 )}$ \\
\hline $\begin{array}{c}\text { One Period Lag of the } \\
\text { Dependent Variable }\end{array}$ & $0.110^{* * *}$ & $0.221^{* * *}$ & $0.298^{* * *}$ \\
\hline & $(0.0334)$ & $(0.0182)$ & $(0.0136)$ \\
\hline PCI & $-0.0321^{* * *}$ & $-0.0851^{* * *}$ & $-0.0838^{* * *}$ \\
\hline Log(GDPC) & $(0.00763)$ & $(0.0103)$ & $(0.0109)$ \\
\hline OPEN & $0.316^{* * *}$ & $0.701^{* * *}$ & $0.596^{* * *}$ \\
\hline & $(0.0387)$ & $(0.0498)$ & $(0.0432)$ \\
\hline FINPOL & $-0.222^{* * *}$ & -0.00690 & $-0.435^{* * *}$ \\
\hline INFL & $(0.0444)$ & $(0.0738)$ & $0.0735)$ \\
\hline & $0.233^{* * *}$ & $0.382^{* * *}$ & $0.379^{* * *}$ \\
\hline FINDEV & $(0.0693)$ & $(0.109)$ & $(0.0991)$ \\
\hline & $0.0720^{* * *}$ & $0.113^{* * *}$ & $0.191^{* * *}$ \\
\hline & $(0.0251)$ & $(0.0397)$ & $0.0327)$ \\
\hline & -0.153 & $-1.746^{* * *}$ & $1.297 * * *$ \\
\hline Observations - Countries & $(0.261)$ & $(0.316)$ & $(0.467)$ \\
\hline Number of Instruments & $433-118$ & & $536-118$ \\
\hline AR1 (P-Value) & 76 & $536-118$ & 89 \\
\hline AR2 (P-Value) & 0.0000 & 89 & 0.0000 \\
\hline Sargan (P-Value) & 0.3143 & 0.0000 & 0.4055 \\
\hline
\end{tabular}

Note: ${ }^{*}$-value $<0.1 ;{ }^{*}$ p-value $<0.05 ; * * *$-value $<0.01$. Robust standard errors are in parenthesis. In the two-step system GMM estimations, the variables "PCI", "FINPOL", "OPEN", "INFL" and "FINDEV" have been treated as endogenous. The regressions have used a maximum of 3 lags of the dependent variable as instruments and 3 lags of the endogenous variables as instruments. Time dummies have been included in the regressions. 
Table 3: Effect of productive capacities on economic resilience in LDCs versus NonLDCs Estimator: Two-Step System GMM

\begin{tabular}{|c|c|c|}
\hline Variables & RESILGMM & RESILGMM \\
\hline & $(1)$ & (2) \\
\hline \multirow[t]{2}{*}{ RESILGMM $_{\mathrm{t}-1}$} & $0.0684^{* *}$ & $0.0993^{* * *}$ \\
\hline & $(0.0285)$ & $(0.0275)$ \\
\hline \multirow[t]{2}{*}{ PCI } & $-0.0472^{* * *}$ & $0.0286^{*}$ \\
\hline & $(0.00950)$ & $(0.0163)$ \\
\hline \multirow[t]{2}{*}{ PCI*LDC } & $0.0338^{* * *}$ & \\
\hline & $(0.0104)$ & \\
\hline \multirow[t]{2}{*}{ LDC } & $-0.883^{* * *}$ & \\
\hline & $(0.254)$ & \\
\hline \multirow[t]{2}{*}{$\mathrm{PCI}^{*}[\log (\mathrm{GDPC})]$} & & $-0.00737 * * *$ \\
\hline & & $(0.00159)$ \\
\hline \multirow[t]{2}{*}{ Log(GDPC) } & $0.323^{* * *}$ & $0.512^{* * *}$ \\
\hline & $(0.0451)$ & $(0.0496)$ \\
\hline \multirow[t]{2}{*}{ OPEN } & $-0.149 * * *$ & $-0.145^{* * *}$ \\
\hline & $(0.0377)$ & $(0.0366)$ \\
\hline \multirow[t]{2}{*}{ FINPOL } & $0.232^{* * *}$ & $0.235^{* * *}$ \\
\hline & $(0.0635)$ & $(0.0596)$ \\
\hline \multirow[t]{2}{*}{ INFL } & $0.0632^{* *}$ & $0.0564 * * *$ \\
\hline & $(0.0250)$ & $(0.0211)$ \\
\hline \multirow[t]{2}{*}{ FINDEV } & -0.197 & -0.146 \\
\hline & $(0.227)$ & $(0.221)$ \\
\hline Observations - Countries & $433-118$ & $433-118$ \\
\hline Number of Instruments & 86 & 86 \\
\hline AR1 (P-Value) & 0.0000 & 0.0000 \\
\hline AR2 (P-Value) & 0.2986 & 0.3282 \\
\hline OID (P-Value) & 0.2627 & 0.2492 \\
\hline
\end{tabular}

Note: ${ }^{*}$-value $<0.1$; ${ }^{* *} p$-value $<0.05$; *** $p$-value $<0.01$. Robust standard errors are in parenthesis. In the two-step system GMM estimations, the variables "PCI", "FINPOL", "OPEN", "INFL", "FINDEV" and the interaction variables have been treated as endogenous. The regressions have used a maximum of 3 lags of the dependent variable as instruments and 3 lags of the endogenous variables as instruments. Time dummies have been included in the regressions. 
Table 4: Effect of productive capacities on economic resilience over the full sample

Estimator: Two-Step System GMM

\begin{tabular}{|c|c|c|c|c|c|c|c|c|}
\hline Variables & RESILGMM & RESILGMM & RESILGMM & RESILGMM & RESILGMM & RESILGMM & RESILGMM & RESILGMM \\
\hline & (1) & (2) & (3) & (4) & (5) & (6) & (7) & (8) \\
\hline \multirow[t]{2}{*}{ RESILGMM $_{\mathrm{t}-1}$} & $0.0607^{* *}$ & $0.0892^{* * *}$ & $0.0737^{* *}$ & $0.0535^{* *}$ & $0.115^{* * *}$ & $0.0591^{* *}$ & $0.0892^{* * *}$ & $0.0867 * * *$ \\
\hline & $(0.0247)$ & $(0.0343)$ & $(0.0330)$ & $(0.0228)$ & $(0.0348)$ & $(0.0248)$ & $(0.0282)$ & $(0.0333)$ \\
\hline \multirow{2}{*}{ HUMCAP } & $-0.00658^{* *}$ & & & & & & & \\
\hline & $(0.00288)$ & & & & & & & \\
\hline \multirow[t]{2}{*}{ NATURAL } & & 0.00115 & & & & & & \\
\hline & & $(0.00244)$ & & & & & & \\
\hline \multirow[t]{2}{*}{ ENERG } & & & $-0.00775^{* * *}$ & & & & & \\
\hline & & & $(0.00207)$ & & & & & \\
\hline \multirow[t]{2}{*}{ TRANSP } & & & & $-0.00633^{* * *}$ & & & & \\
\hline & & & & $(0.00233)$ & & & & \\
\hline \multirow[t]{2}{*}{ ICT } & & & & & $-0.0180^{* *}$ & & & \\
\hline & & & & & $(0.00737)$ & & & \\
\hline \multirow[t]{2}{*}{ INST } & & & & & & $-0.00618^{* * * *}$ & & \\
\hline & & & & & & $(0.00221)$ & & \\
\hline \multirow[t]{2}{*}{ PRIVATE } & & & & & & & -0.00405 & \\
\hline & & & & & & & $(0.00354)$ & \\
\hline \multirow[t]{2}{*}{ SCI } & & & & & & & & -0.00584 \\
\hline & & & & & & & & $(0.00816)$ \\
\hline \multirow[t]{2}{*}{ Log(GDPC) } & $0.223^{* * *}$ & $0.326^{* * *}$ & $0.301^{* * *}$ & $0.324^{* * *}$ & $0.291^{* * *}$ & 0.339 *** & $0.292^{* * *}$ & $0.245^{* * *}$ \\
\hline & $(0.0186)$ & $(0.0288)$ & $(0.0381)$ & $(0.0284)$ & $(0.0329)$ & $(0.0247)$ & $(0.0270)$ & $(0.0248)$ \\
\hline \multirow[t]{2}{*}{ OPEN } & $-0.134 * * *$ & $-0.103^{* * *}$ & $-0.129 * * *$ & $-0.0999 * * *$ & $-0.223^{* * *}$ & $-0.101 * * *$ & $-0.204 * * *$ & $-0.208^{* * *}$ \\
\hline & $(0.0341)$ & $(0.0342)$ & $(0.0437)$ & $(0.0371)$ & $(0.0425)$ & $(0.0354)$ & $(0.0469)$ & $(0.0443)$ \\
\hline \multirow[t]{2}{*}{ FINPOL } & 0.0650 & 0.0361 & -0.0542 & $0.155^{\text {*** }}$ & $0.176^{* * *}$ & $0.206^{* * *}$ & $0.293^{* * *}$ & 0.0703 \\
\hline & $(0.0478)$ & $(0.0759)$ & $(0.0691)$ & $(0.0560)$ & $(0.0620)$ & $(0.0535)$ & $(0.101)$ & $(0.0747)$ \\
\hline \multirow[t]{2}{*}{ INFL } & $0.154^{* * *}$ & $0.121^{* * *}$ & $0.0684^{* *}$ & $0.101^{* * *}$ & $0.0980^{* * *}$ & $0.109^{* * *}$ & $0.0982^{* * *}$ & $0.113^{* * *}$ \\
\hline & $(0.0223)$ & $(0.0305)$ & $(0.0286)$ & $(0.0199)$ & $(0.0277)$ & $(0.0192)$ & $(0.0240)$ & $(0.0269)$ \\
\hline FINDEV & -0.0910 & $-1.050 * * *$ & $-0.511 *$ & $-1.173^{* * *}$ & $-0.713^{* * *}$ & $-1.033^{* * *}$ & $-1.252^{* * *}$ & -0.333 \\
\hline
\end{tabular}




\begin{tabular}{|c|c|c|c|c|c|c|c|c|}
\hline & $(0.251)$ & $(0.247)$ & $(0.267)$ & $(0.240)$ & $(0.212)$ & $(0.250)$ & $(0.270)$ & $(0.332)$ \\
\hline Observations - Countries & $433-118$ & $433-118$ & $433-118$ & $433-118$ & $433-118$ & $433-118$ & $433-118$ & $433-118$ \\
\hline Number of Instruments & 88 & 76 & 76 & 88 & 76 & 88 & 76 & 76 \\
\hline AR1 (P-Value) & 0.0000 & 0.0000 & 0.0000 & 0.0000 & 0.0000 & 0.0000 & 0.0000 & 0.0000 \\
\hline AR2 (P-Value) & 0.2876 & 0.3349 & 0.2885 & 0.2711 & 0.3608 & 0.2892 & 0.3252 & 0.3121 \\
\hline OID (P-Value) & 0.1402 & 0.10 & 0.1138 & 0.1149 & 0.1295 & 0.1242 & 0.1030 & 0.1561 \\
\hline
\end{tabular}

Note: ${ }^{*} p$-value $<0.1 ; * *$-value $<0.05 ; * * *$-value $<0.01$. Robust standard errors are in parenthesis. In the two-step system GMM estimations, the variables "PCI" (and its components),

"FINPOL", "OPEN", "INFL", "FINDEV" and the interaction variables have been treated as endogenous. The regressions have used a maximum of 3 lags of the dependent variable as instruments and 2 lags of the endogenous variables as instruments. Time dummies bave been included in the regressions. 
Table 5: Effect of productive capacities on economic resilience for varying levels of development aid flows_Over the full sample

Estimator: Two-Step System GMM

\begin{tabular}{|c|c|c|c|c|c|c|}
\hline Variables & RESILGMM & RESILGMM & RESILGMM & RESILGMM & RESILGMM & RESILGMM \\
\hline & $(1)$ & (2) & (3) & (4) & (5) & (6) \\
\hline \multirow[t]{2}{*}{ RESILGMM $_{\mathrm{t}-1}$} & $0.0877 * *$ & $0.0641 * *$ & $0.0933^{* * *}$ & $0.0957 * * *$ & 0.109 *** & $0.0495 * *$ \\
\hline & $(0.0373)$ & $(0.0303)$ & $(0.0315)$ & $(0.0257)$ & $(0.0301)$ & $(0.0218)$ \\
\hline \multirow[t]{2}{*}{ PCI } & $-0.0271^{* *}$ & $-0.251^{* * *}$ & $-0.237^{* * *}$ & $-0.358^{* * *}$ & $-0.266^{* * *}$ & $-0.245^{* * *}$ \\
\hline & $(0.0126)$ & $(0.0603)$ & $(0.0476)$ & $(0.0462)$ & $(0.0391)$ & $(0.0439)$ \\
\hline \multirow[t]{2}{*}{$\log (\mathrm{ODA})$} & -0.0435 & $-0.319 * * *$ & & & & \\
\hline & $(0.0270)$ & $(0.0823)$ & & & & \\
\hline \multirow[t]{2}{*}{ PCI*Log(ODA) } & & $0.0115^{* * *}$ & & & & \\
\hline & & $(0.00307)$ & & & & \\
\hline \multirow[t]{2}{*}{ PCI*[Log(AfTTOT) $]$} & & & $-0.0114 * * *$ & & & \\
\hline & & & $(0.00253)$ & & & \\
\hline \multirow[t]{2}{*}{ Log(AfTTOT) } & & & $0.310^{* * *}$ & & & \\
\hline & & & $(0.0851)$ & & & \\
\hline \multirow[t]{2}{*}{ PCI*[Log(AfTINFRA)] } & & & & $-0.00847 * * *$ & & \\
\hline & & & & $(0.00184)$ & & \\
\hline \multirow[t]{2}{*}{ Log(AfTINFRA) } & & & & $0.277^{* * *}$ & & \\
\hline & & & & $(0.0620)$ & & \\
\hline \multirow[t]{2}{*}{ PCI*[Log(AfTPROD)] } & & & & & $-0.0100 * * *$ & \\
\hline & & & & & $(0.00236)$ & \\
\hline \multirow[t]{2}{*}{ Log(AfTPROD) } & & & & & $0.248^{* * *}$ & \\
\hline & & & & & $(0.0755)$ & \\
\hline \multirow[t]{2}{*}{ PCI* $[\log ($ AfTPOL $)]$} & & & & & & $-0.00430 * * *$ \\
\hline & & & & & & $(0.00107)$ \\
\hline \multirow[t]{2}{*}{ Log(AfTPOL) } & & & & & & $0.104^{* * *}$ \\
\hline & & & & & & $(0.0317)$ \\
\hline \multirow[t]{2}{*}{ PCI*[Log(NonAfT'TOT)] } & & & $0.0210^{* * *}$ & $0.0237 * * *$ & $0.0216^{* * *}$ & $0.0140 * * *$ \\
\hline & & & $(0.00331)$ & $(0.00234)$ & $(0.00259)$ & $(0.00236)$ \\
\hline \multirow[t]{2}{*}{ Log(NonAfTTOT) } & & & $-0.559 * * *$ & $-0.671^{* * *}$ & $-0.571 * * *$ & $-0.347 * * *$ \\
\hline & & & $(0.0915)$ & $(0.0740)$ & $(0.0724)$ & $(0.0718)$ \\
\hline \multirow[t]{2}{*}{$\log ($ GDPC) } & $0.313^{* * *}$ & $0.315^{* * *}$ & $0.377 * * *$ & $0.401^{* * *}$ & $0.282^{* * *}$ & $0.357^{* * *}$ \\
\hline & $(0.0743)$ & $(0.0618)$ & $(0.0462)$ & $(0.0451)$ & $(0.0425)$ & $(0.0362)$ \\
\hline \multirow[t]{2}{*}{ OPEN } & -0.0519 & -0.0972 & 0.0467 & 0.0175 & 0.0589 & $-0.133^{* * *}$ \\
\hline & $(0.0816)$ & $(0.0648)$ & $(0.0628)$ & $(0.0474)$ & $(0.0508)$ & $(0.0479)$ \\
\hline \multirow[t]{2}{*}{ FINPOL } & $0.204 * * *$ & $0.131^{*}$ & $0.0990^{*}$ & $0.173^{* * *}$ & $0.0980^{*}$ & $0.202^{* * *}$ \\
\hline & $(0.0783)$ & $(0.0745)$ & $(0.0581)$ & $(0.0533)$ & $(0.0517)$ & $(0.0647)$ \\
\hline \multirow[t]{2}{*}{ INFL } & $0.166^{* * *}$ & $0.131^{* * *}$ & $0.113^{* * *}$ & $0.0965^{* * *}$ & $0.195^{* * *}$ & $0.0591^{* *}$ \\
\hline & $(0.0356)$ & $(0.0321)$ & $(0.0249)$ & $(0.0224)$ & $(0.0305)$ & $(0.0249)$ \\
\hline \multirow[t]{2}{*}{ FINDEV } & -0.183 & -0.208 & $-0.413^{* *}$ & $-0.591 * * *$ & -0.362 & $-0.401 *$ \\
\hline & $(0.351)$ & $(0.355)$ & $(0.203)$ & $(0.209)$ & $(0.226)$ & $(0.237)$ \\
\hline Observations - Countries & $394-109$ & $394-109$ & $393-109$ & $393-109$ & $393-109$ & $391-109$ \\
\hline Number of Instruments & 65 & 72 & 86 & 86 & 86 & 86 \\
\hline AR1 (P-Value) & 0.0000 & 0.0000 & 0.0000 & 0.0000 & 0.0000 & 0.0000 \\
\hline
\end{tabular}




\begin{tabular}{|l|l|l|l|l|l|l|}
\hline AR2 (P-Value) & 0.2927 & 0.3392 & 0.5472 & 0.5860 & 0.4151 & 0.2916 \\
\hline OID (P-Value) & 0.1876 & 0.1839 & 0.1635 & 0.1356 & 0.2006 & 0.2425 \\
\hline
\end{tabular}

Note: * ${ }^{*}$-value $<0.1$; $^{*} p$-value $<0.05$; ***p-value $<0.01$. Robust standard errors are in parenthesis. In the two-step system GMM estimations, the variables "PCI", aid variables, "FINPOL", "OPEN", "INFL", "FINDEV" and the interaction variables have been treated as endogenous. The regressions have used a maximum of 3 lags of the dependent variable as instruments and 2 lags of the endogenous variables as instruments. Time dummies have been included in the regressions. 
Table 6: Effect of the interaction between productive capacities and countries' features on economic resilience_ Over the full sample

Estimator: Two-Step System GMM

\begin{tabular}{|c|c|c|c|c|c|}
\hline Variables & RESILGMM $_{t}$ & RESILGMM $_{t}$ & RESILGMM $_{\mathrm{t}}$ & RESILGMM $_{\mathrm{t}}$ & RESILGMM $_{t}$ \\
\hline & (1) & $(2)$ & (3) & (4) & (5) \\
\hline \multirow{2}{*}{ RESILGMM $_{\mathrm{t}-1}$} & $0.118^{* * *}$ & $0.113^{* * *}$ & $0.0842^{* *}$ & $0.0927 * * *$ & $0.101 * * *$ \\
\hline & $(0.0272)$ & $(0.0321)$ & $(0.0385)$ & $(0.0298)$ & $(0.0267)$ \\
\hline \multirow[t]{2}{*}{ PCI } & $-0.0304^{* * *}$ & -0.0125 & $-0.0188^{*}$ & $-0.0426 * * *$ & $-0.0340 * * *$ \\
\hline & $(0.00737)$ & $(0.00880)$ & $(0.0111)$ & $(0.00695)$ & $(0.00860)$ \\
\hline \multirow[t]{2}{*}{ PCI*OPEN } & -0.000836 & $-0.0257 * * *$ & & & \\
\hline & $(0.00189)$ & $(0.00794)$ & & & \\
\hline \multirow[t]{2}{*}{ PCI*FINPOL } & & & $-0.0613^{* * *}$ & & \\
\hline & & & $(0.0126)$ & & \\
\hline \multirow[t]{2}{*}{ PCI*INFL } & & & & $0.00641 * * *$ & \\
\hline & & & & $(0.00232)$ & \\
\hline \multirow[t]{2}{*}{ PCI*FINDEV } & & & & & 0.00382 \\
\hline & & & & & $(0.0111)$ \\
\hline \multirow[t]{2}{*}{$\log ($ GDPC $)$} & $0.302^{* * *}$ & $0.200^{* * *}$ & $0.343^{* * *}$ & $0.284^{* * *}$ & $0.327 * * *$ \\
\hline & $(0.0303)$ & $(0.0289)$ & $(0.0610)$ & $(0.0263)$ & $(0.0337)$ \\
\hline \multirow[t]{2}{*}{ FINPOL } & $0.231^{* * *}$ & $0.333^{* * *}$ & $2.047 * * *$ & $0.266^{* * *}$ & $0.217^{* * *}$ \\
\hline & $(0.0537)$ & $(0.0481)$ & $(0.411)$ & $(0.0526)$ & $(0.0539)$ \\
\hline \multirow[t]{2}{*}{ OPEN } & $-0.150^{* *}$ & $0.659 * * *$ & $-0.315^{* * *}$ & $-0.187 * * *$ & $-0.203^{* * *}$ \\
\hline & $(0.0714)$ & $(0.248)$ & $(0.0750)$ & $(0.0334)$ & $(0.0361)$ \\
\hline \multirow[t]{2}{*}{ INFL } & $0.0799 * * *$ & 0.0262 & -0.0348 & $-0.134^{*}$ & $0.0686^{* * *}$ \\
\hline & $(0.0172)$ & $(0.0250)$ & $(0.0359)$ & $(0.0796)$ & $(0.0185)$ \\
\hline \multirow[t]{2}{*}{ FINDEV } & -0.0969 & 0.196 & -0.0369 & -0.0591 & -0.195 \\
\hline & $(0.206)$ & $(0.216)$ & $(0.344)$ & $(0.233)$ & $(0.399)$ \\
\hline \multirow[t]{2}{*}{ Constant } & $-1.686^{* * *}$ & $-1.444 * * *$ & $-2.001 * * *$ & $-1.133 * * *$ & $-1.739 * * *$ \\
\hline & $(0.158)$ & $(0.269)$ & $(0.360)$ & $(0.210)$ & $(0.174)$ \\
\hline Observations - Countries & $433-118$ & $417-114$ & $433-118$ & $433-118$ & $433-118$ \\
\hline Number of Instruments & 86 & 86 & 65 & 86 & 86 \\
\hline AR1 (P-Value) & 0.0000 & 0.0000 & 0.0000 & 0.0000 & 0.0000 \\
\hline AR2 (P-Value) & 0.3393 & 0.2779 & 0.2729 & 0.3682 & 0.2886 \\
\hline OID (P-Value) & 0.2988 & 0.1994 & 0.1293 & 0.1332 & 0.3694 \\
\hline
\end{tabular}

Note: ${ }^{*} p$-value $<0.1{ }^{* *} p$-value $<0.05$; ${ }^{* *} p$-value $<0.01$. Robust standard errors are in parenthesis. In the two-step system

GMM estimations, the variables "PCI", "FINPOL", "OPEN", "INFL", "FINDEV" and the interaction variables

have been treated as endogenous. The regressions have used a maximum of 3 lags of the dependent variable as instruments and

2 lags of the endogenous variables as instruments. Time dummies have been included in the regressions. 
Appendix 1: Definition and Source of variables

\begin{tabular}{|c|c|c|}
\hline Variables & Definition & Sources \\
\hline RESILGMM & $\begin{array}{l}\text { This is the index of economic resilience computed using the two-step system GMM } \\
\text { estimator (it is a relative indicator of economic resilience). It has been obtained } \\
\text { using the following formula (e.g., Yeyati et al. 2007): RESILGMM = } \\
\text { sign(RESILGMM1) * log ( } 1 \text { + |RESILGMM1|), where |RESILGMM1| refers to } \\
\text { the absolute value of the economic resilience indicator denoted "RESILGMM1", } \\
\text { which has been obtained as the residual of the regression of the indicator of } \\
\text { economic growth volatility on the index of structural economic vulnerability. } \\
\text { We have transformed "RESILGMM1" into "RESILGMM" using the formula above } \\
\text { because the distribution of "RESILGMM1" is highly skewed, and this variable } \\
\text { additionally contains negative and positive values. }\end{array}$ & $\begin{array}{l}\text { Author's computation (see Section 4). The economic } \\
\text { growth volatility indicator has been computed as It } \\
\text { has been computed as the rolling standard deviation } \\
\text { over a 3-year-window of the economic growth rate } \\
\text { (i.e., the growth rate of the Gross Domestic Product } \\
\text { (GDP), constant } 2010 \text { US } \$ \text { ). The real GDP variable } \\
\text { is extracted from the World Development Indicators } \\
\text { (WDI) of the World Bank. The indicator of } \\
\text { structural economic vulnerability (denoted "EVI") is } \\
\text { described below. }\end{array}$ \\
\hline RESILFE & $\begin{array}{c}\text { This is the index of economic resilience computed using the within fixed effects } \\
\text { estimator (it is a relative indicator of economic resilience). It has been obtained } \\
\text { using the following formula (e.g., Yeyati et al. 2007): } \\
\text { RESILFE = sign(RESILFE1) * log (1 + |RESILFE1|), where |RESILFE1| refers } \\
\text { to the absolute value of the economic resilience indicator denoted "RESILFE1", } \\
\text { which has been obtained as the residual of the regression of the indicator of } \\
\text { economic growth volatility on the index of structural economic vulnerability. } \\
\text { We have transformed "RESILFE1" into "RESILFE" using the formula above } \\
\text { because the distribution of "RESILFE1" is highly skewed, and this variable, } \\
\text { additionally, contains negative and positive values. }\end{array}$ & Author's calculation (see above). \\
\hline RESILFGLS & $\begin{array}{l}\text { This is the index of economic resilience computed using the feasible generalized } \\
\text { least squares estimator (it is a relative indicator of economic resilience). It has been } \\
\text { obtained using the following formula (e.g., Yeyati et al. 2007): RESILFGLS= } \\
\text { sign(RESILFGLS1) * log (1 + |RESILFGLS1|), where |RESILFGLS1| refers to } \\
\text { the absolute value of the economic resilience indicator denoted "RESILFGLS1", } \\
\text { which has been obtained as the residual of the regression of the indicator of } \\
\text { economic growth volatility on the index of structural economic vulnerability. }\end{array}$ & Author's calculation (see above). \\
\hline
\end{tabular}




\begin{tabular}{|c|c|c|}
\hline & $\begin{array}{c}\text { We have transformed "RESILFGLS1" into "RESILFGLS" using the formula above } \\
\text { because the distribution of "RESILFGLS" is highly skewed, and this variable, } \\
\text { additionally, contains negative and positive values. }\end{array}$ & \\
\hline PCI & $\begin{array}{l}\text { This is the overall Productive Capacity Index. It measures the level of productive } \\
\text { capacities along three pillars: "the productive resources, entrepreneurial capabilities } \\
\text { and production linkages which together determine the capacity of a country to } \\
\text { produce goods and services and enable it to grow and develop" (UNCTAD, 2006). } \\
\text { It is computed as a geometric average of eight domains or categories, namely, } \\
\text { Information communication and technologies (ICTs), structural change, natural } \\
\text { capital, human capital, energy, transport, the private sector and institutions. Each } \\
\text { category index is obtained from the principal components extracted from the } \\
\text { underlying indicators, weighted by their capacity to explain the variance of the } \\
\text { original data. The category indices are normalized into 0-100 intervals. } \\
\text { The components of "PCI" include ICTs (denoted "ICT"), structural change } \\
\text { (denoted "SCI"), natural capital (denoted "NATURAL"), human capital (denoted } \\
\text { "HUMCAP"), energy (denoted "ENERG"), transport (denoted "TRANSP"), the } \\
\text { private sector (denoted "PRIVATE"), and institutions (denoted "INST"). }\end{array}$ & $\begin{array}{c}\text { United Nations Conference on Trade and } \\
\text { Development (UNCTAD) Statistics portal: } \\
\text { https://unctadstat.unctad.org/wds/ReportFolders /r } \\
\text { eportFolders.aspx } \\
\text { See UNCTAD (2020) for a complete description of } \\
\text { the methodology used to compute the indicator } \\
\text { "PCI". }\end{array}$ \\
\hline $\begin{array}{c}\text { ODA, } \\
\text { AfTTOT, } \\
\text { AfTINFRA, } \\
\text { AfTPROD, } \\
\text { AfTPOL }\end{array}$ & $\begin{array}{l}\text { "ODA" is the real gross disbursements of total Official Development Assistance } \\
\text { (ODA) expressed in constant prices 2018, US Dollar. "AfTTOT" is the total real } \\
\text { gross disbursements of Aid for Trade. "AfTINFRA" is the real gross disbursements } \\
\text { of Aid for Trade allocated to the buildup of economic infrastructure. "AfTPROD" } \\
\text { is the real gross disbursements of Aid for Trade for building productive capacities. } \\
\text { "AfTPOL" is the real gross disbursements of Aid allocated for trade policies and } \\
\text { regulation. All four AfT variables are expressed in constant prices } 2018 \text {, US Dollar. }\end{array}$ & $\begin{array}{l}\text { Author's calculation based on data extracted from } \\
\text { the database OECD statistical database on } \\
\text { development, in particular the OECD/DAC-CRS } \\
\text { (Organization for Economic Cooperation and } \\
\text { Development/Donor Assistance Committee)-Credit } \\
\text { Reporting System (CRS). Aid for Trade data cover } \\
\text { the following three main categories (the CRS Codes } \\
\text { are in brackets): } \\
\text { Aid for Trade for Economic Infrastructure } \\
\text { ("AfTINFRA"), which includes transport and } \\
\text { storage (210), communications (220), and energy } \\
\text { generation and supply (230); } \\
\text { Aid for Trade for Building Productive Capacity } \\
\text { ("AfTPROD"), which includes banking and financial }\end{array}$ \\
\hline
\end{tabular}




\begin{tabular}{|c|c|c|}
\hline & & $\begin{array}{l}\text { services (240), business and other services (250), } \\
\text { agriculture (311), forestry (312), fishing (313), industry } \\
\text { (321), mineral resources and mining (322), and } \\
\text { tourism (332); and } \\
\text { Aid for Trade policy and regulations ("AfTPOL"), } \\
\text { which includes trade policy and regulations and trade- } \\
\text { related adjustment (331). }\end{array}$ \\
\hline NonAfT'TOT & $\begin{array}{l}\text { This is the measure of the development aid allocated to other sectors in the } \\
\text { economy than the trade sector. It has been computed as the difference between the } \\
\text { gross disbursements of total ODA and the gross disbursements of total Aid for } \\
\text { Trade (both being expressed in constant prices 2018, US Dollar). }\end{array}$ & $\begin{array}{l}\text { Author's calculation based on data extracting from } \\
\text { the OECD/DAC-CRS database. }\end{array}$ \\
\hline EVI & $\begin{array}{l}\text { This is indicator of structural economic vulnerability, also referred to as the } \\
\text { Economic Vulnerability Index. The "EVI" is developed by the United Nations } \\
\text { Committee for Development Policy (CDP), and regularly updated on a } \\
\text { retrospective and yearly basis by the FERDI (Foundation for Studies and Research } \\
\text { on International Development) (e.g., Feindouno and Goujon, 2016). It is the simple } \\
\text { arithmetic average of two sub-indexes, which are the intensity of exposure to } \\
\text { shocks (exposure sub-index) and the intensity of exogenous shocks (shocks sub- } \\
\text { index). In turn, these two sub-indexes have been computed using a weighted } \\
\text { average of different component indexes, with the sum of components' weights } \\
\text { being equal to } 1 \text { so that the values of EVI range between } 0 \text { and } 100 \text {. } \\
\text { The exposure sub-index has five component indexes, and the shocks sub-index has } \\
\text { three component indexes. The five component indexes of the exposure sub-index } \\
\text { (with their weights in brackets) are: population size ( } 25 \% \text { ), remoteness from world } \\
\text { markets ( } 25 \% \text { ), exports concentration (12.5\%), share of agriculture, forestry and } \\
\text { fishery in GDP (12.5\%) and the share of population living in low elevated coastal } \\
\text { zone ( } 25 \% \text { ). The three component indexes of the shocks sub-index (with their } \\
\text { weights in brackets) are: the victims of natural disasters ( } 25 \% \text { ), the instability in the } \\
\text { agricultural production ( } 25 \% \text { ), and the instability in exports of goods and services } \\
\text { (50\%). A rise in the values of EVI indicate greater structural economic vulnerability. }\end{array}$ & $\begin{array}{l}\text { Data on EVI is extracted from the database of the } \\
\text { Fondation pour les Etudes et Recherches sur le } \\
\text { Developpement International (FERDI) - see online } \\
\text { at: } \underline{\text { https:// ferdi.fr/donnees / un-indicateur-de- }} \\
\text { vulnerabilite-economique-evi-retrospectif }\end{array}$ \\
\hline
\end{tabular}




\begin{tabular}{|c|c|c|}
\hline & $\begin{array}{l}\text { For further details on the computation of the EVI, see for example Feindouno and } \\
\text { Goujon (2016). }\end{array}$ & \\
\hline FINDEV & $\begin{array}{l}\text { This is the financial development index, which summarizes how developed financial } \\
\text { institutions and financial markets are in terms of their depth (size and liquidity), } \\
\text { access (ability of individuals and companies to access financial services), and } \\
\text { efficiency (ability of institutions to provide financial services at low costs and with } \\
\text { sustainable revenues, and the level of activity of capital markets). }\end{array}$ & $\begin{array}{l}\text { Data extracted from the IMF Financial Development } \\
\text { Index Database (see online at: } \\
\frac{\text { https://data.imf.org/?sk=F8032E80-B36C-43B1- }}{\text { AC26-493C5B1CD33B) - See also Sahay et al. }} \\
\text { (2015). }\end{array}$ \\
\hline GDPC & Per capita Gross Domestic Product (constant 2010 US\$). & WDI \\
\hline INFL & $\begin{array}{l}\text { The variable "INFL" has been calculated using the following formula (e.g., Yeyati et } \\
\text { al. 2007): INFL }=\operatorname{sign}(\text { INFLATION) } * \log (1+\mid \text { INFLATION|) (2), where } \\
\mid \text { INFLATION| refers to the absolute value of the annual inflation rate (\%), denoted } \\
\text { "INFLATION". The annual inflation rate (\%) is based on consumer price index - } \\
\text { CPI- (annual } \% \text { ) where missing values have been replaced with values of the GDP } \\
\text { Deflator (annual } \%) \text {. }\end{array}$ & Author's calculation based on data from the WDI. \\
\hline FINPOL & This is the measure of financial policy, i.e., de jure financial openness. & $\begin{array}{l}\text { This index has been computed by Chinn and Ito } \\
(2006) \text { and updated in July } 2020 \text {. Its value ranges } \\
\text { between } 0 \text { and } 1 \text {. See: } \\
\text { http://web.pdx.edu/ ito/Chinn-Ito website.htm } \\
\text { For the purpose of the present study, we have } \\
\text { transformed this index by multiplying its values by } \\
\text { 100. So, its values range here between } 0 \text { and } 100 \text {. }\end{array}$ \\
\hline OPEN & $\begin{array}{l}\text { Measure of trade openness calculated as the share of sum of exports and imports of } \\
\text { goods and services in GDP. This variable is not expressed in percentage. }\end{array}$ & $\begin{array}{l}\text { Author's calculation based on data extracted from } \\
\text { the WDI }\end{array}$ \\
\hline
\end{tabular}
goods and services in GDP. This variable is not expressed in percentage. 
Appendix 2: Descriptive statistics on variables used in the model over the full sample

\begin{tabular}{|c|c|c|c|c|c|}
\hline Variable & Observations & Mean & Standard deviation & Minimum & Maximum \\
\hline RESILGMM1 & 547 & 0.011 & 0.528 & -1.596 & 1.818 \\
\hline RESILFGLS1 & 547 & -0.016 & 1.998 & -2.779 & 15.674 \\
\hline RESILFE1 & 547 & -0.061 & 2.590 & -7.871 & 13.494 \\
\hline PCI & 546 & 27.541 & 5.972 & 12.873 & 44.850 \\
\hline HUMCAP & 546 & 43.155 & 10.138 & 20.341 & 87.523 \\
\hline NATURAL & 546 & 53.830 & 8.679 & 32.952 & 92.075 \\
\hline ENERG & 546 & 24.593 & 6.964 & 6.771 & 58.484 \\
\hline TRANSP & 546 & 15.025 & 6.726 & 4.522 & 58.009 \\
\hline ICT & 546 & 7.833 & 4.456 & 2.824 & 29.727 \\
\hline INST & 546 & 47.660 & 14.631 & 16.587 & 92.289 \\
\hline PRIVATE & 546 & 75.566 & 8.947 & 38.160 & 93.821 \\
\hline SCI & 546 & 17.154 & 4.642 & 1.880 & 36.890 \\
\hline FINPOL & 547 & 0.432 & 0.345 & 0.000 & 1.000 \\
\hline OPEN & 544 & 0.811 & 0.458 & 0.002 & 4.190 \\
\hline INFLATION & 547 & 6.542 & 9.871 & -6.701 & 188.343 \\
\hline FINDEV & 547 & 0.249 & 0.166 & 0.011 & 0.857 \\
\hline ODA & 507 & 852 & 1010 & 0.29 & 5850 \\
\hline AfTTOT & 499 & 212 & 365 & 0.067224 & 3380 \\
\hline AfTINFRA & 499 & 125 & 243 & 0.013896 & 2530 \\
\hline AfTPROD & 499 & 83 & 141 & 0.029398 & 1550 \\
\hline AfTPOL & 487 & 4.103 & 11.9 & 0.000025 & 188 \\
\hline NonAfTTOT & 499 & 651 & 753 & 4.133839 & 5150 \\
\hline GDPC & 546 & 6654.459 & 10308.89 & 218.3344 & 67312.96 \\
\hline
\end{tabular}

Note: The variables "ODA", "AfTTOT", "AfTINFRA", "AfTPROD", "AfTPOL" and "NonAfTTOT" are expressed in millions of US\$.

Appendix 3: List of countries contained in the Full Sample

\begin{tabular}{|c|c|c|c|c|}
\hline \multicolumn{4}{|c|}{ Full sample } & LDCs \\
\hline Algeria & Equatorial Guinea & Mauritius & Tunisia & Angola \\
\hline Angola & Eswatini & Mexico & Turkey & Bangladesh \\
\hline Argentina & Ethiopia & Mongolia & Turkmenistan & Benin \\
\hline Armenia & Fiji & Morocco & Uganda & Bhutan \\
\hline Azerbaijan & Gabon & Mozambique & $\begin{array}{c}\text { United Arab } \\
\text { Emirates }\end{array}$ & Burkina Faso \\
\hline Bahamas, The & Gambia, The & Myanmar & Uruguay & Burundi \\
\hline Bahrain & Georgia & Namibia & Uzbekistan & Cambodia \\
\hline Bangladesh & Ghana & Nepal & Venezuela, RB & $\begin{array}{c}\text { Central A frican } \\
\text { Republic } \\
\end{array}$ \\
\hline Barbados & Grenada & Nicaragua & Vietnam & Chad \\
\hline Belize & Guatemala & Niger & Zambia & Comoros \\
\hline Benin & Guinea & Nigeria & & $\begin{array}{c}\text { Congo, Dem. } \\
\text { Rep. }\end{array}$ \\
\hline Bhutan & Guinea-Bissau & Oman & & Ethiopia \\
\hline Bolivia & Haiti & Pakistan & & Gambia, The \\
\hline $\begin{array}{c}\text { Bosnia and } \\
\text { Herzegovina }\end{array}$ & Honduras & Panama & & Guinea \\
\hline
\end{tabular}




\begin{tabular}{|c|c|c|c|}
\hline Brazil & India & Paraguay & Guinea-Bissau \\
\hline Burkina Faso & Indonesia & Peru & Haiti \\
\hline Burundi & Iran, Islamic Rep. & Philippines & Lao PDR \\
\hline Cabo Verde & Israel & Qatar & Lesotho \\
\hline Cambodia & Jamaica & Rwanda & Liberia \\
\hline Cameroon & Jordan & Samoa & Madagascar \\
\hline $\begin{array}{c}\text { Central African } \\
\text { Republic }\end{array}$ & Kazakhstan & Saudi Arabia & Malawi \\
\hline Chad & Kenya & Senegal & Mali \\
\hline Chile & Korea, Rep. & Seychelles & Mauritania \\
\hline China & Kuwait & Sierra Leone & Mozambique \\
\hline Colombia & Kyrgyz Republic & Singapore & Myanmar \\
\hline Comoros & Lao PDR & Solomon Islands & Nepal \\
\hline $\begin{array}{l}\text { Congo, Dem. } \\
\text { Rep. }\end{array}$ & Lebanon & South Africa & Niger \\
\hline Congo, Rep. & Lesotho & Sri Lanka & Rwanda \\
\hline Costa Rica & Liberia & $\begin{array}{l}\text { St. Vincent and } \\
\text { the Grenadines }\end{array}$ & Senegal \\
\hline Cote d'Ivoire & Madagascar & Sudan & Sierra Leone \\
\hline Cyprus & Malawi & Suriname & Solomon Islands \\
\hline Dominica & Malaysia & Tajikistan & Sudan \\
\hline $\begin{array}{l}\text { Dominican } \\
\text { Republic }\end{array}$ & Maldives & Tanzania & Tanzania \\
\hline Ecuador & Mali & Thailand & Togo \\
\hline Egypt, Arab Rep. & Marshall Islands & Togo & Uganda \\
\hline El Salvador & Mauritania & Tonga & Zambia \\
\hline
\end{tabular}

